\title{
Summary of Previous Mechanical Test Data on ODS Alloys 14YWT and OFRAC up to $1000^{\circ} \mathrm{C}$
}

David T. Hoelzer

May 2021 


\title{
DOCUMENT AVAILABILITY
}

Reports produced after January 1, 1996, are generally available free via US Department of Energy (DOE) SciTech Connect.

Website www.osti.gov

Reports produced before January 1, 1996, may be purchased by members of the public from the following source:

\author{
National Technical Information Service \\ 5285 Port Royal Road \\ Springfield, VA 22161 \\ Telephone 703-605-6000 (1-800-553-6847) \\ TDD 703-487-4639 \\ Fax 703-605-6900 \\ E-mail info@ntis.gov \\ Website http://classic.ntis.gov/
}

Reports are available to DOE employees, DOE contractors, Energy Technology Data Exchange representatives, and International Nuclear Information System representatives from the following source:

Office of Scientific and Technical Information

PO Box 62

Oak Ridge, TN 37831

Telephone 865-576-8401

Fax 865-576-5728

E-mail reports@osti.gov

Website http://www.osti.gov/contact.html

This report was prepared as an account of work sponsored by an agency of the United States Government. Neither the United States Government nor any agency thereof, nor any of their employees, makes any warranty, express or implied, or assumes any legal liability or responsibility for the accuracy, completeness, or usefulness of any information, apparatus, product, or process disclosed, or represents that its use would not infringe privately owned rights. Reference herein to any specific commercial product, process, or service by trade name, trademark, manufacturer, or otherwise, does not necessarily constitute or imply its endorsement, recommendation, or favoring by the United States Government or any agency thereof. The views and opinions of authors expressed herein do not necessarily state or reflect those of the United States Government or any agency thereof. 
Materials Science and Technology Division

\title{
SUMMARY OF PREVIOUS MECHANICAL TEST DATA ON ODS ALLOYS 14YWT AND OFRAC UP TO $1000^{\circ} \mathrm{C}$
}

\author{
David T. Hoelzer
}

April 2021

\author{
Prepared by \\ OAK RIDGE NATIONAL LABORATORY \\ Oak Ridge, TN 37831-6283 \\ managed by \\ UT-BATTELLE LLC \\ for the \\ US DEPARTMENT OF ENERGY \\ under contract DE-AC05-00OR22725
}




\section{AKNOWLEDGEMENTS}

Financial support for this research was provided by the Advanced Research Projects Agency - Energy (ARPA-E), U.S. Department of Energy. The author is grateful for Caleb P. Massey and Thak Sang Byun for reviewing this summary report and Eric T. Manneschmidt and Ian A. Stinson for their assistance with the tensile and creep tests. 


\begin{abstract}
The Nanostructured Ferritic Alloys (NFA) 14YWT and OFRAC were developed for future fission and fusion nuclear energy reactors requiring high-temperature mechanical properties that are tolerant to extreme neutron irradiation environments. The NFA contain a high concentration of Ti-, Y- and O-enriched nanoclusters (NC) and ultra-fine grains to achieve high temperature strength and creep properties and high sink strength for trapping irradiation induced point defects to minimize hardening and swelling and transmutated $\mathrm{He}$ atoms to form intragranular nano-size bubbles that prevent formation of coarse bubbles on grain boundaries that cause embrittlement. The mechanical properties of 14YWT and OFRAC have been acquired from tensile and creep tests conducted in the past at Oak Ridge National Laboratory. The development of 14YWT started in 2000, resulting in the production of numerous heats. Tensile properties were obtained from eleven heats of $14 \mathrm{YWT}$ from room temperature to $800^{\circ} \mathrm{C}$. Tensile data for the SM10 heat of $14 \mathrm{YWT}$ was extended to $1,000^{\circ} \mathrm{C}$. Initial development of OFRAC occurred in 2016. Tensile tests conducted from room temperature to $800^{\circ} \mathrm{C}$ revealed similar properties of OFRAC with those obtained from the newer generation of 14YWT heats. The creep properties of 14YWT-SM10 evaluated using constant stress tensile and load time-to-failure tests at $800^{\circ} \mathrm{C}$ showed low minimum creep rates with stresses of 200 and $100 \mathrm{MPa}$. The single time-to-failure test of $14 \mathrm{YWT}-\mathrm{SM} 10$ at $800^{\circ} \mathrm{C}$ and $100 \mathrm{MPa}$ was terminated after 20,357 hours with no specimen failure and a low creep strain of $\sim 0.24 \%$. The creep properties of OFRAC determined from strain-rate jump tests at were similar those of 14YWT-SM10. The stress exponent for 14YWT and OFRAC at $800^{\circ} \mathrm{C}$ are similar and are consistent with threshold stress behavior. Since both 14YWT and OFRAC are candidates for fuel cladding in future fast reactors, several fabrication studies were recently conducted and have successfully demonstrated that thin wall tubes can be fabricated from 14YWT and OFRAC by cold pilger rolling and high precision tube rolling. The high temperature mechanical properties and feasibility of fabricating thin wall tubes make 14YWT and OFRAC candidates for application as heat pipes in advanced micro-reactors. The purpose of this report is to summarize the previously obtained tensile and creep data at temperatures up to $1000^{\circ} \mathrm{C}$ for NFA 14 YWT and OFRAC that have been acquired over the past 20 years at ORNL.
\end{abstract}




\section{CONTENTS}

\section{Page}

ACKNOWLEDGMENTS.

iv

ABSTRACT......

1. INTRODUCTION

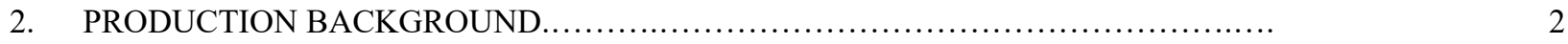

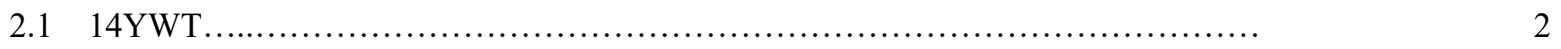

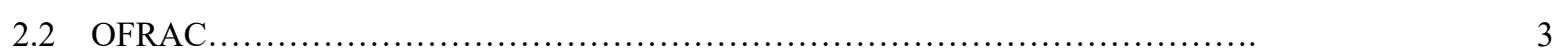

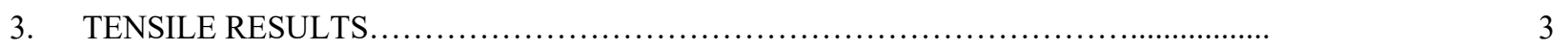

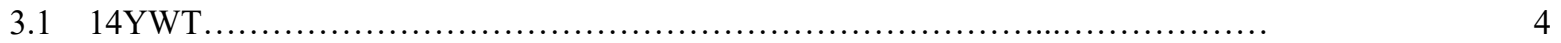

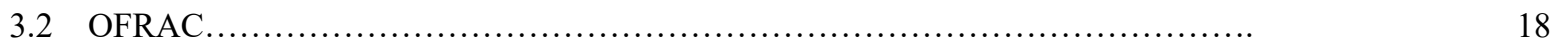

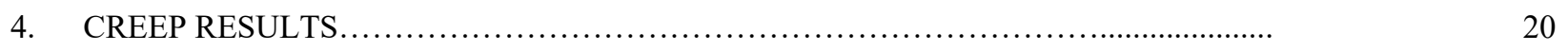

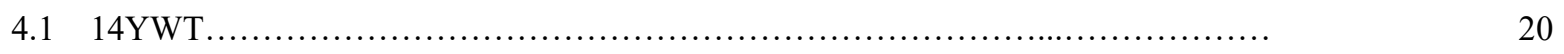

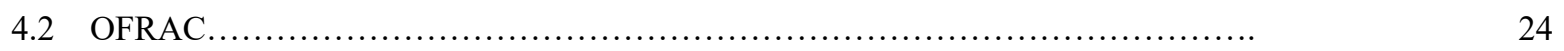

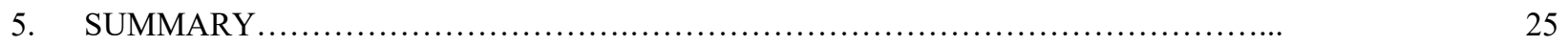




\section{INTRODUCTION}

Advanced oxide dispersion strengthened (ODS) ferritic alloys, which are referred to as Nanostructured Ferritic Alloys (NFA) possess attractive high-temperature mechanical properties and are tolerant to extreme irradiation environments of future nuclear and fusion energy reactors. Following the discovery of Ti-, Yand O-enriched nano-size clusters, i.e. nanoclusters (NC), in the ODS 12YWT ferritic alloy that was developed in Japan in the late 1990's and subsequently in MA957, which was developed and patented by INCO in 1978, development of NFA 14YWT (Fe-14Cr-3 $\left.\underline{\mathrm{W}}-0.4 \underline{\mathrm{T}} \mathrm{i}+0.3 \underline{\mathrm{Y}}_{2} \mathrm{O}_{3}\right)$ was initiated in 2000 at Oak Ridge National Laboratory. The goals for developing 14YWT were obtaining a microstructure containing a high concentration of $\mathrm{NC}$ with ultra-fine grains to achieve high temperature strength and creep properties and high sink strength for trapping irradiation induced point defects as well as transmutated He atoms to prevent their migration to grain boundaries to form bubbles. Early research identified the mechanical alloying conditions that consistently led to the dispersion of NC consisting of 2-4 nm diameter in size and $>5$ $\mathrm{x} 10^{23} \mathrm{~m}^{-3}$ number densities and grain sizes typically less than $\sim 500 \mathrm{~nm}$. A highlight obtained from 14YWT (SM6 heat) in 2008 was the combination of high strength $\left(\sigma_{\mathrm{ys}}=1460 \mathrm{MPa}\right.$ and $\left.\sigma_{\text {uts }}=1610 \mathrm{MPa}\right)$ and high fracture toughness $(\sim 178 \mathrm{MPa} \sqrt{\mathrm{m}})$ at room temperature and low fracture toughness transition temperature of $-150^{\circ} \mathrm{C}$ that was unaffected by neutron irradiation to $\sim 1.5 \mathrm{dpa}$ at $300^{\circ} \mathrm{C}$ in the HFIR irradiation experiment. Another highlight was achieving very high strength properties with 14YWT (SM10 heat). However, the low fracture toughness properties of SM10 at elevated temperatures prompted new processing efforts to control contamination of powders during ball milling, which recently have been linked to significant improvements in the high-temperature fracture toughness properties. The NFA OFRAC (ak

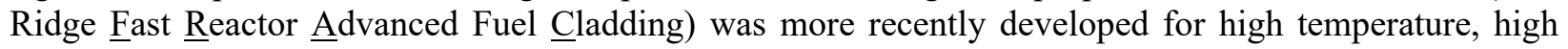
neutron dose environments of advanced nuclear reactors.

Both 14YWT and OFRAC are candidate NFA's for fuel cladding in future fast reactors. Although the high strength of these NFA's at low temperatures presents significant challenges for fabricating thin wall tubing, recent efforts using cold pilger rolling and cold high precision tube rolling (HPTR) successfully demonstrated that thin wall tubing can be fabricated from 14YWT and OFRAC. Recently, a thin wall tube of 14YWT with dimensions of $10.7 \mathrm{~mm}$ OD, $0.5 \mathrm{~mm}$ WT and $0.92 \mathrm{~m}$ in length was fabricated by cold pilger rolling campaign in collaboration with CEA, Saclay, France. Two recent campaigns in collaboration with Nippon Nuclear Fuel Development (NFD) Co., LTD, Japan, resulted in the fabrication of a thin wall tube of OFRAC that was $8.5 \mathrm{~mm}$ OD $+0.5 \mathrm{~mm}$ WT and $1.78 \mathrm{~m}$ in length by cold pilger rolling and most recently in 2020 , four thin wall tubes $(6 \mathrm{~mm}$ OD $+0.5 \mathrm{~mm}$ WT and $>2.2 \mathrm{~m}$ in length) were fabricated by (HPTR). The successful fabrication of thin wall tubes from NFA 14YWT and OFRAC may allow for other applications such as heat pipes in micro-reactors. Therefore, the purpose of this report is to summarize previously obtained tensile and creep data at temperatures up to $1000^{\circ} \mathrm{C}$ for NFA $14 \mathrm{YWT}$ and OFRAC that have been acquired over the past 20 years at ORNL. 


\section{PRODUCTION BACKGROUND}

\subsubsection{YWT}

The development of NFA 14YWT began at ORNL in 2001 and continued with several Nuclear Energy (NE) programs through 2019. The initial development of 14YWT began with the Laboratory Directed Research and Development (LDRD) project at ORNL from 2001 to 2003. Further development of 14YWT occurred during the International Nuclear Energy Initiative (INERI) project between ORNL and CEA, Saclay, France from 2002 to 2005 and was restarted in 2007. In 2008, the NE Fuel Cycle Research and Development (FCRD) program picked up support for development of 14YWT as fuel cladding in sodium fast reactors until the 2019 when funding ended in the Advanced Reactors program of the NE Advanced Fuel Campaign (AFC).

Table 1 lists the 14YWT heats that were produced in the LDRD and NE programs through about 2015. The $\mathrm{CR}$ and SM heat designations are abbreviations of the companies that produced the pre-alloyed powders of 14YWT by Ar gas atomization: CR for Crucible Research (now ATI Powder Metals) and SM for Special Metals. These powders were purchased during the LDRD project with similar compositions of Fe- $14 \mathrm{Cr}-$ $3 \mathrm{~W}-0.4 \mathrm{Ti}$ (wt.\%) with slight differences in the specifications for the primary solute additions and undesirable substitutional and interstitial elements notably $\mathrm{O}, \mathrm{C}$ and $\mathrm{N}$. The FCRD program focused on scale up of 14YWT and improved processing procedures. For this program, a contract was established with ATI Powder Metals to produce a large heat ( $\sim 5 \mathrm{lbs}$.) of Fe pre-alloyed powder containing a small addition of Y by Ar gas atomization. Powder with composition of Fe-14Cr-3W-0.4Ti-0.2Y was successfully achieved by ATI Powder Metals. The 14YWT heats that were produced by this processing method have the designation of NFA for Nanostructured Ferritic $\underline{\text { Alloy. }}$

The processing conditions for producing the 14YWT heats are shown in Table 1. This includes the powder mass for ball milling and the extrusion factors such as die shape, reduction ratio, temperature, and date. The $200 \mathrm{~g}$ powder mass of early heats from CR1 to SM10 was the maximum quantity of powder that could be ball milled using high kinetic energy CM01 Simoloyer manufactured by Zoz, GmbH. The larger powder masses of SM6, SM7, SM8 and SM10 were produced using multiple ball milling runs on 200g batches and blending the milled powders together prior to extrusion. ACM08 Simoloyer was purchased at the beginning of the FCRD program that could ball mill up to 1,000 $\mathrm{g}$ of powder, which accounted for the larger powder masses of SM11, SM12 and SM13. The extrusion conditions used for producing the CR1, CR2, SM1 and CR3 heats were different from those used later since these represented the early development phase of 14YWT. The first two heats of CR1 and CR2 were extruded as rods through a circular die at $1175^{\circ} \mathrm{C}$ and high reduction ratio of 16:1. The microstructural studies of these heats showed that a relatively low number density of coarse oxide particles formed instead of the goal of high number density of nano-size Y-Ti-O particles which was the goal of the alloy development efforts. The extrusion temperature was subsequently lowered to $850^{\circ} \mathrm{C}$ and the microstructural studies confirmed the presence of a high number density of nanosize Y-Ti-O particles. However, the ball milling parameters were not optimized and the microstructure of both heats contained a bi-modal grain size distribution in which the nano-size Y-Ti-O particles were only present in the ultra-fine grain regions. Improved ball milling conditions resulted in the significant uniformity in grain size and dispersion of Y-Ti-O particles for the SM3, CR4, SM4 heats. In general, the optimized ball milling conditions have been used for producing virtually all the subsequent heats of 14YWT shown in Table 1. The main differences are the switch from producing rods using the circular die to bars using the rectangular die, the latter to facilitate hot rolling to form plates of 14YWT for studies of mechanical properties and joining by friction stir welding. In recent years, the AFC (formerly FCRD) program has focused on fabrication of thin wall fuel cladding. For this effort, extrusions using a circular die were used to form solid master rods. The central region of the master rods was gun drilled to form the master tubes by Nippon NFD co., Japan. 
Table 1. List of the mass of ball milled powder and extrusion parameters that included die shape, reduction ratio, temperature, and date for the 14YWT heats.

\begin{tabular}{|c|c|c|c|c|c|}
\hline \multirow{2}{*}{ Heat } & \multicolumn{5}{|c|}{ Extrusion Factors } \\
\cline { 2 - 6 } & $\begin{array}{c}\text { Mass } \\
(\mathrm{g})\end{array}$ & Die & $\begin{array}{c}\text { Reduction } \\
\text { Ratio }\end{array}$ & $\begin{array}{c}\text { Temperature } \\
\left({ }^{\circ} \mathrm{C}\right)\end{array}$ & Date \\
\hline CR1 & 200 & Circular & $16: 1$ & 1175 & $09 / 18 / 2001$ \\
\hline CR2 & 200 & Circular & $16: 1$ & 1175 & $01 / 14 / 2002$ \\
\hline SM1 & 200 & Circular & $4: 1$ & 850 & $04 / 29 / 2002$ \\
\hline CR3 & 200 & Circular & $4: 1$ & 850 & $04 / 29 / 2002$ \\
\hline SM3 & 200 & Circular & $7: 1$ & 850 & $03 / 17 / 2004$ \\
\hline CR4 & 200 & Circular & $7: 1$ & 850 & $03 / 17 / 2004$ \\
\hline SM4 & 200 & Circular & $7: 1$ & 850 & $03 / 17 / 2004$ \\
\hline SM5 & 200 & Circular & $7: 1$ & 850 & $09 / 17 / 2004$ \\
\hline SM6 & 800 & Circular & $7: 1$ & 850 & $01 / 03 / 2005$ \\
\hline SM7 & 1000 & Circular & $7: 1$ & 850 & $08 / 03 / 2005$ \\
\hline SM8 & 1000 & Circular & $7: 1$ & 850 & $08 / 03 / 2005$ \\
\hline SM9 & 200 & Circular & $7: 1$ & 850 & $08 / 03 / 2005$ \\
\hline SM10 & 1200 & Rectangular & $6.3: 1$ & 850 & $06 / 27 / 2007$ \\
\hline SM11 & 1600 & Rectangular & $4: 1$ & 850 & $02 / 11 / 2010$ \\
\hline SM12a (200) & 750 & Rectangular & $6.3: 1$ & 850 & $02 / 02 / 2011$ \\
\hline SM12c (185) & 750 & Rectangular & $6.3: 1$ & 850 & $03 / 31 / 2011$ \\
\hline SM12d (170) & 750 & Rectangular & $6.3: 1$ & 850 & $03 / 31 / 2011$ \\
\hline SM13 & 5400 & Rectangular & $4: 1$ & 850 & $03 / 20 / 2012$ \\
\hline NFA1 & 5.443 & Rectangular & $4: 1$ & 850 & $10 / 19 / 2012$ \\
\hline
\end{tabular}

\subsection{OFRAC}

The NFA OFRAC was recently developed for fuel cladding in $\mathrm{Na}$ fast reactors based on extensive experience gained on mechanical alloying and alloy composition during development of the NFA 14YWT. The nominal composition of OFRAC is Fe-12Cr-1Mo-0.3Ti-0.3Nb-0.3 $\mathrm{Y}_{2} \mathrm{O}_{3}$ (wt.\%). The mechanical alloying conditions that were developed for 14YWT over many years were used for producing OFRAC in both bar and rod shapes.

\section{TENSILE RESULTS}

The tensile results from room temperature up to $800^{\circ} \mathrm{C}$ are significantly more extensive for 14YWT than for OFRAC due to the much longer development period of $\sim 20$ years resulting in multiple heats. For OFRAC, the initial heat was produced in 2016, which all the microstructure and mechanical properties characterization results were obtained prior to subsequent heats that were produced for two thin wall tube fabrication campaigns. 


\subsection{YWT}

Tensile tests were conducted on 11 heats of 14YWT that are listed in Table 2. The type of tensile specimen and figure number showing the stress-strain curves from $25^{\circ} \mathrm{C}$ to $800^{\circ} \mathrm{C}$ for all $14 \mathrm{YWT}$ heats except 14YWT-SM6, which was tested from $25^{\circ} \mathrm{C}$ to $700^{\circ} \mathrm{C}$, and $14 \mathrm{YWT}-\mathrm{SM} 10$, which was tested up to $1000^{\circ} \mathrm{C}$, are also shown in Table 2. The two types of specimens used in the tensile tests were SS-J3 and SS-3. These were flat specimens having dimensions shown in Figure 1. The smaller SS-J3 specimens were primarily fabricated from the early 14YWT heats due to the smaller $200 \mathrm{~g}$ mass and from some heats that included SS-J3 specimens in neutron irradiation experiments such as 14YWT-SM7 for ATR irradiation experiments sponsored by the Navy and the three 14YWT-SM12 heats for HFIR JP30-31 irradiation experiments sponsored by the Fusion Materials Program at ORNL. All of the tensile tests performed on the 11 heats of 14YWT were conducted in air using a nominal strain rate of $1 \times 10^{-3} \mathrm{~s}^{-1}$.

Table 2. The type of specimens used in the tensile tests on the eleven 14YWT heats and the figure number showing the representative stress-strain curves.

\begin{tabular}{|c|c|c|}
\hline Heat & $\begin{array}{c}\text { Tensile } \\
\text { Specimen }\end{array}$ & Figure \\
\hline CR2 & SS-J3 & 2 \\
\hline CR4 & SS-J3 & 3 \\
\hline SM4 & SS-J3 & 4 \\
\hline SM6 & SS-3 & 5 \\
\hline SM7 & SS-J3 & 6 \\
\hline SM10 & SS-3 & 7 \\
\hline SM12a & SS-J3 & 8 \\
\hline SM12c & SS-J3 & 9 \\
\hline SM12d & SS-J3 & 10 \\
\hline SM13 & SS-3 & 11 \\
\hline NFA1 & SS-3 & 12 \\
\hline
\end{tabular}

Figures 2 to 12 show the stress-strain curves for each test temperature that was conducted on the 14YWT heats listed in Table 2. All of the heats except for CR2 had yield stresses (YS) and ultimate tensile strengths (UTS) at room temperature that were above 1,000 MPa. The CR2 heat (Fig. 2) was an early generation heat that was extruded at $1175^{\circ} \mathrm{C}$ (Table 1), which was based on the processing data published for 12YWT that was found to contain a high number density of nano-size Y-Ti-oxygen clusters [1]. The microstructure analysis of CR2 by transmission electron microscopy (TEM) showed a dispersion of coarse oxide dispersion instead of nano-size Y-Ti-oxygen clusters that were observed in the 12YWT [2]. The YS and UTS of CR2 decreased significantly as the test temperature was increased to $800^{\circ} \mathrm{C}$. The extrusion temperature was lowered to $850^{\circ} \mathrm{C}$ (Table 1) for producing CR4 (Fig. 3) and SM4 (Fig. 4), which were found to contain the high number density of nano-size Y-Ti-O clusters, or nanoclusters [2]. The tensile strengths of CR4 and SM4 were significantly higher than CR2 from room temperature to $800^{\circ} \mathrm{C}$. The ductility properties of CR4 and SM4 were very good over the entire test temperature range considering the high strength levels of these heats. 
(a)

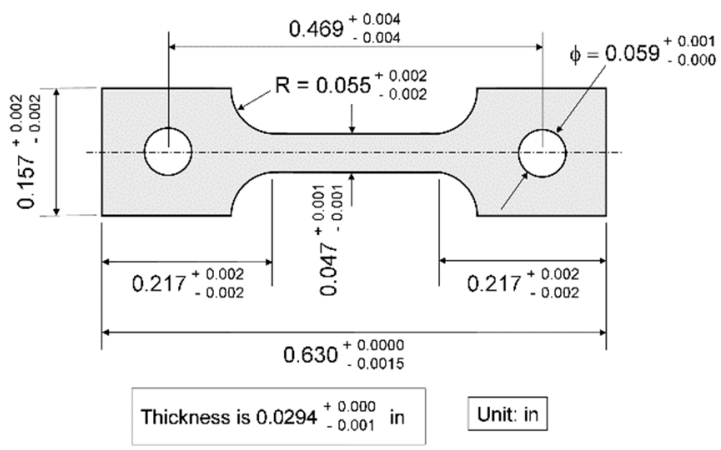

(b)

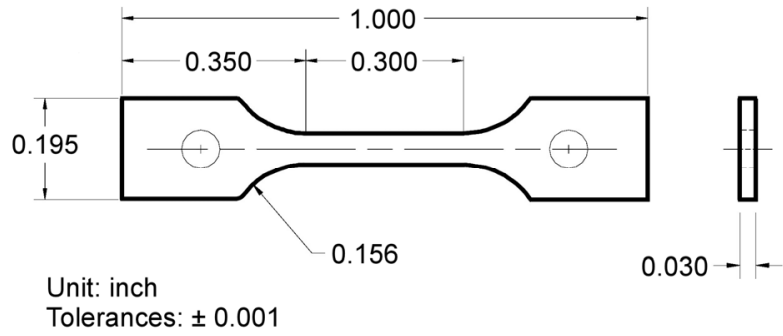

Figure 1. Dimensions of the (a) SS-J3 and (b) SS-3 flat specimens used in the tensile tests.

The tensile curves for 14YWT-SM6 (Fig. 5) showed similar behaviors of strength and ductility as SM4 to $700^{\circ} \mathrm{C}$ [3]. However, SM6 showed a different plastic flow behavior at $23^{\circ} \mathrm{C}$ and $300^{\circ} \mathrm{C}$ than SM4. After the YS is reached, the stress increases rapidly to UTS with little uniform elongation (UE) followed by a rapid drop in stress with further strain. Both SM7 (Fig. 6) and SM10 (Fig. 7) showed similar behavior in the stress-strain curve as that of SM7. However, these two heats recorded the highest values of YS and UTS compared to all the other 14YWT heats.

The 14YWT-SM10 heat was the focus of two publications that covered detailed microstructure characterization results and modeling the temperature-dependent strengthening mechanisms [4,5]. These studies determined that the strengthening mechanisms of SM10 from $-196^{\circ} \mathrm{C}$ to $1000^{\circ} \mathrm{C}$ consisted of contributions from Peierls stress, grain boundary strengthening, particle strengthening, grain matrix hardening and dislocation forest hardening [5]. Significant strengthening from Peierls stress occurs below room temperature for bcc alloys, such as 14YWT, since the intrinsic friction forces responsible for thermally activated deformation dominates. Grain boundary strengthening was the most significant component of the yield strength from room temperature to over $800^{\circ} \mathrm{C}$ due to the ultra-small grain size of $\sim 160 \mathrm{~nm}$ for SM10. The second major component to yield strength in this temperature range was from particle strengthening due to the high number density of Y-Ti-O nanoclusters. The decoration of grain boundaries by nucleation of Y-Ti-oxide particles can influence the stability of the grain size at elevated temperatures. A strengthening contribution from dislocation forest hardening occurs due to interactions between dislocations that can impede mobile dislocations. There is a strengthening contribution from grain matrix but this would be similar in all 14YWT heats due to the same composition of the powders used to produce them. Thus, variations that are observed in the strength properties of the 14YWT heats will depend on differences in these strengthening mechanisms.

Although 14YWT-SM10 (Fig. 7) possessed the highest strengths from room temperature to $800^{\circ} \mathrm{C}$, it showed poor ductility at all temperatures. Another issue with high strength properties was determined from the investigation of fracture toughness for SM10, which showed that the fracture toughness was above 140 $\mathrm{MPa} \sqrt{\mathrm{m}}$ below room temperature to $200^{\circ} \mathrm{C}$, but decreased rapidly to values of $52-82 \mathrm{MPa} \sqrt{\mathrm{m}}$ above $200^{\circ} \mathrm{C}$ to $700^{\circ} \mathrm{C}[6]$. These results led to further developments on $14 \mathrm{YWT}$ by improving the mechanical alloying conditions for lowering the contamination of powders with interstitial $\mathrm{O}, \mathrm{N}$ and $\mathrm{C}$ during ball milling. Three SM12 heats were produced for exploring the effects of lower $\mathrm{O}, \mathrm{N}$ and $\mathrm{C}$ contamination levels compared to past 14YWT heats and extrusion temperature on the tensile and fracture toughness properties [7]. The extrusion temperatures of the SM12 heats (Table 1) were: $1150^{\circ} \mathrm{C}$ for SM12a; $1000^{\circ} \mathrm{C}$ for $12 \mathrm{c}$ and $850^{\circ} \mathrm{C}$ for 12d). The tensile curves for the three SM12 heats are shown in Figure 8 (SM12a), Figure 9 (SM12c) and Figure 10 (SM12d). The most notable differences compared to SM7 (Fig. 6) and SM10 (Fig. 7) are lower strength and higher ductility levels. Furthermore, the strength and ductility levels were similar between SM12a, SM12c and SM12d from room temperature to $800^{\circ} \mathrm{C}$ indicating that lowering $\mathrm{O}, \mathrm{N}$ and $\mathrm{C}$ 
contamination levels had a significant role in causing the variations of strength and ductility properties between the 14YWT heats.

The 14YWT-SM13 heat was produced with the same improved mechanical alloying conditions for lowering the $\mathrm{O}, \mathrm{N}$ and $\mathrm{C}$ levels but the $\mathrm{O}$ level was increased compared to SM12 heats by ball milling a small quantity of $\mathrm{FeO}$ powder. The resulting tensile curves for SM13 shown in Figure 11 exhibit the same ductility characteristics as the SM12 heats over the temperature range of $25^{\circ} \mathrm{C}$ to $800^{\circ} \mathrm{C}$ but higher strength properties. These results indicated that controlling the oxygen level in 14YWT can improve the strength properties without degradation of the ductility properties.

The 14YWT-NFA1 heat was an experimental heat produced with similar powder composition as the past 14YWT heats (Fe-14Cr-3W-0.4Ti) but with metallic Y added to the melt followed by Ar gas atomization to produce powder with the composition $\mathrm{Fe}-14 \mathrm{Cr}-3 \mathrm{~W}-0.4 \mathrm{Ti}-0.2 \mathrm{Y}$. This powder was ball milled with a small quantity of $\mathrm{FeO}$ powder to increase the $\mathrm{O}$ level using the improved mechanical alloying conditions. The tensile curves for NFA1 are shown in Figure 12. Overall, the strength and ductility properties are similar to that of SM12 heats over the temperature range of $25^{\circ} \mathrm{C}$ to $800^{\circ} \mathrm{C}$ indicating that controlling the $\mathrm{O}, \mathrm{N}$ and $\mathrm{C}$ levels leads to lower heat-to-heat variations in mechanical properties of $14 \mathrm{YWT}$. 


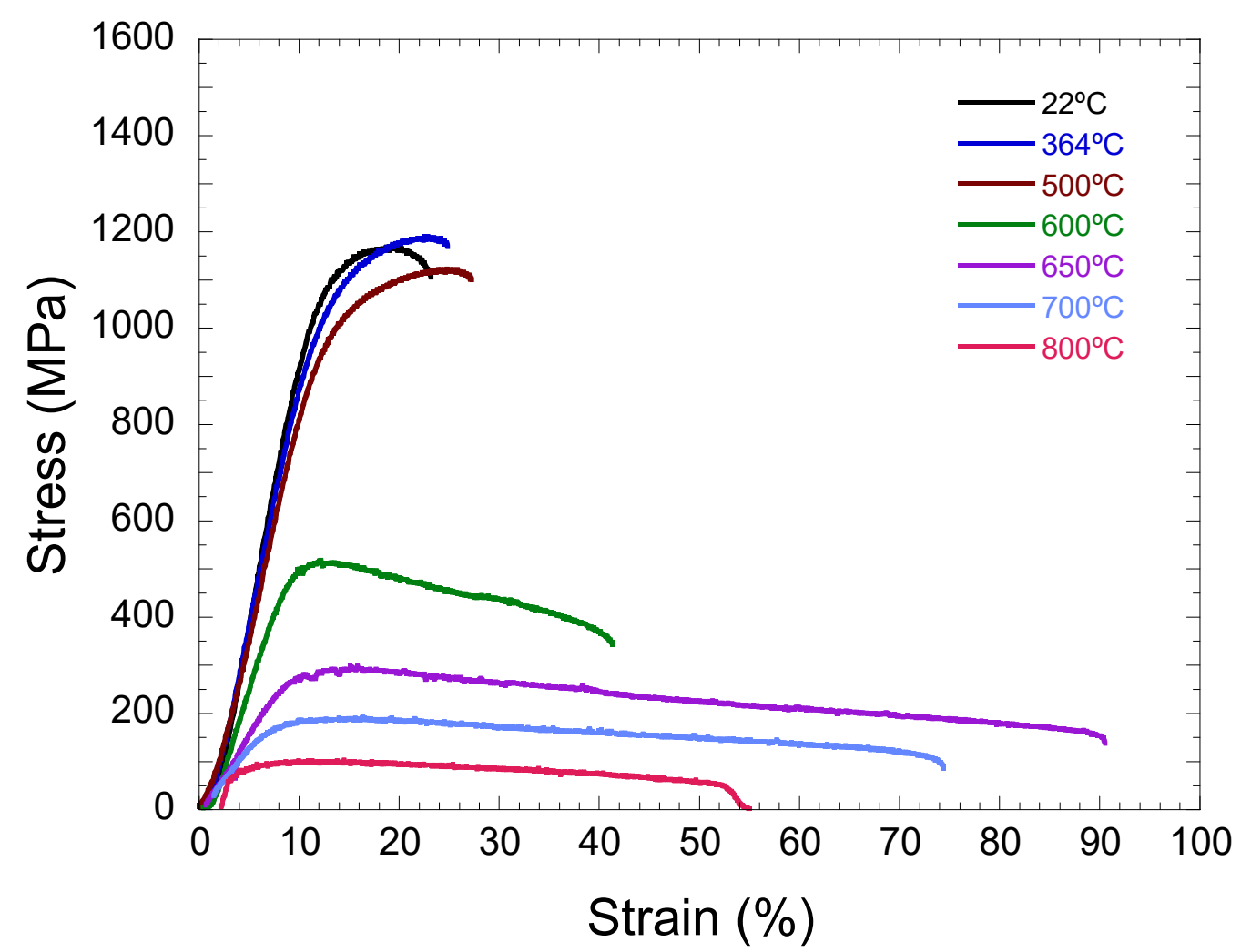

Figure 2. Stress-strain curves of $14 \mathrm{YWT}-\mathrm{CR} 2$ from $25^{\circ} \mathrm{C}$ to $800^{\circ} \mathrm{C}$.

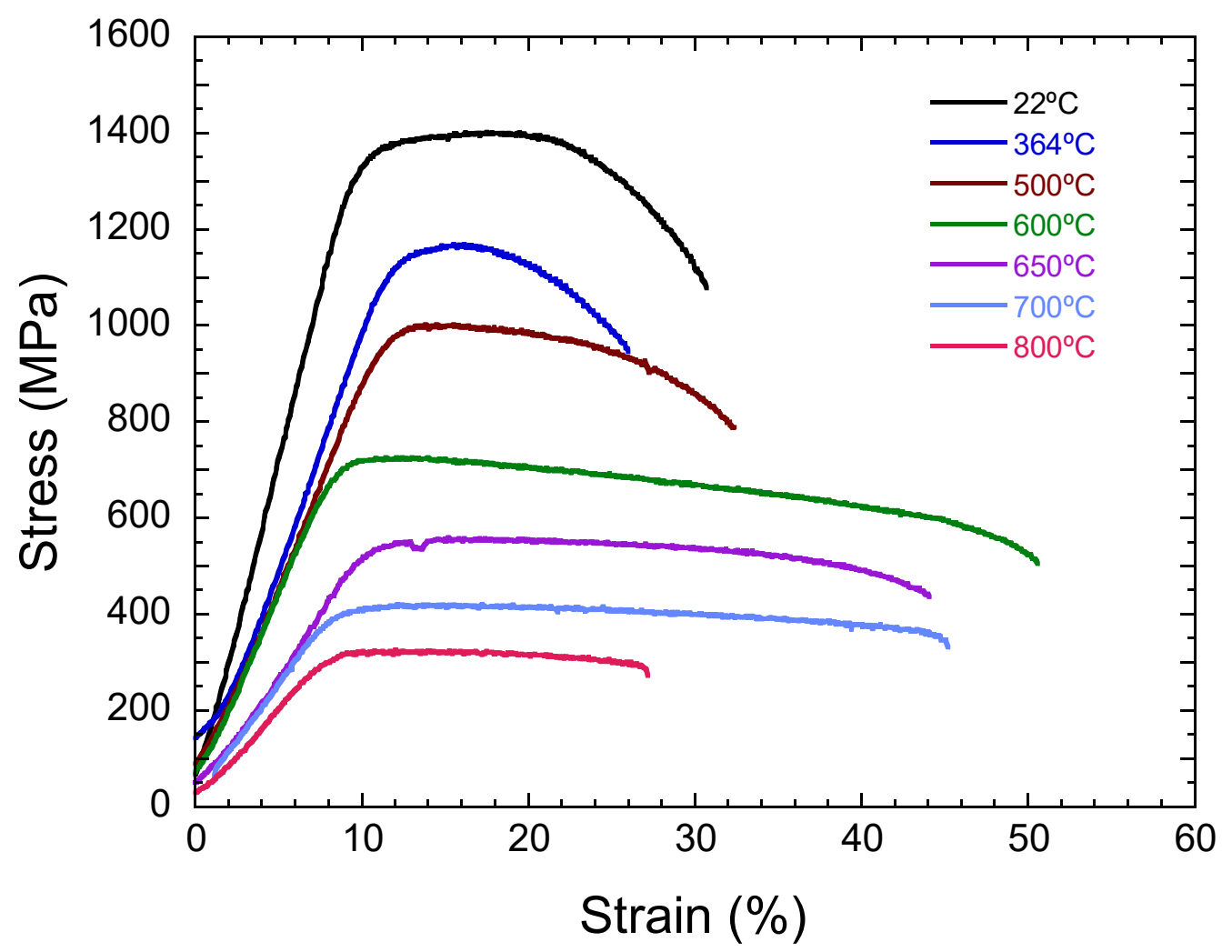

Figure 3. Stress-strain curves of $14 \mathrm{YWT}-\mathrm{CR} 4$ from $25^{\circ} \mathrm{C}$ to $800^{\circ} \mathrm{C}$. 


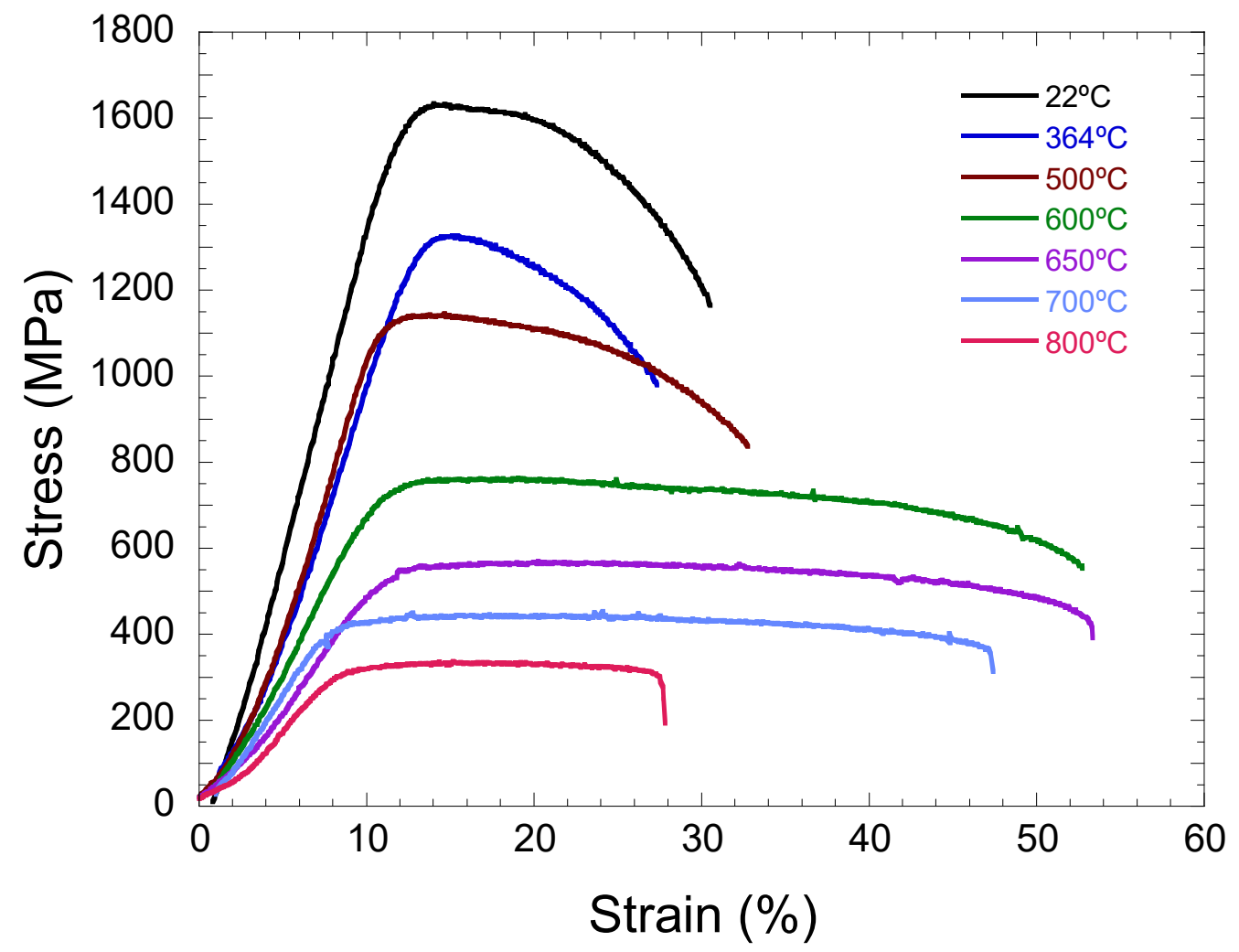

Figure 4. Stress-strain curves of $14 \mathrm{YWT}$-SM4 from $25^{\circ} \mathrm{C}$ to $800^{\circ} \mathrm{C}$.

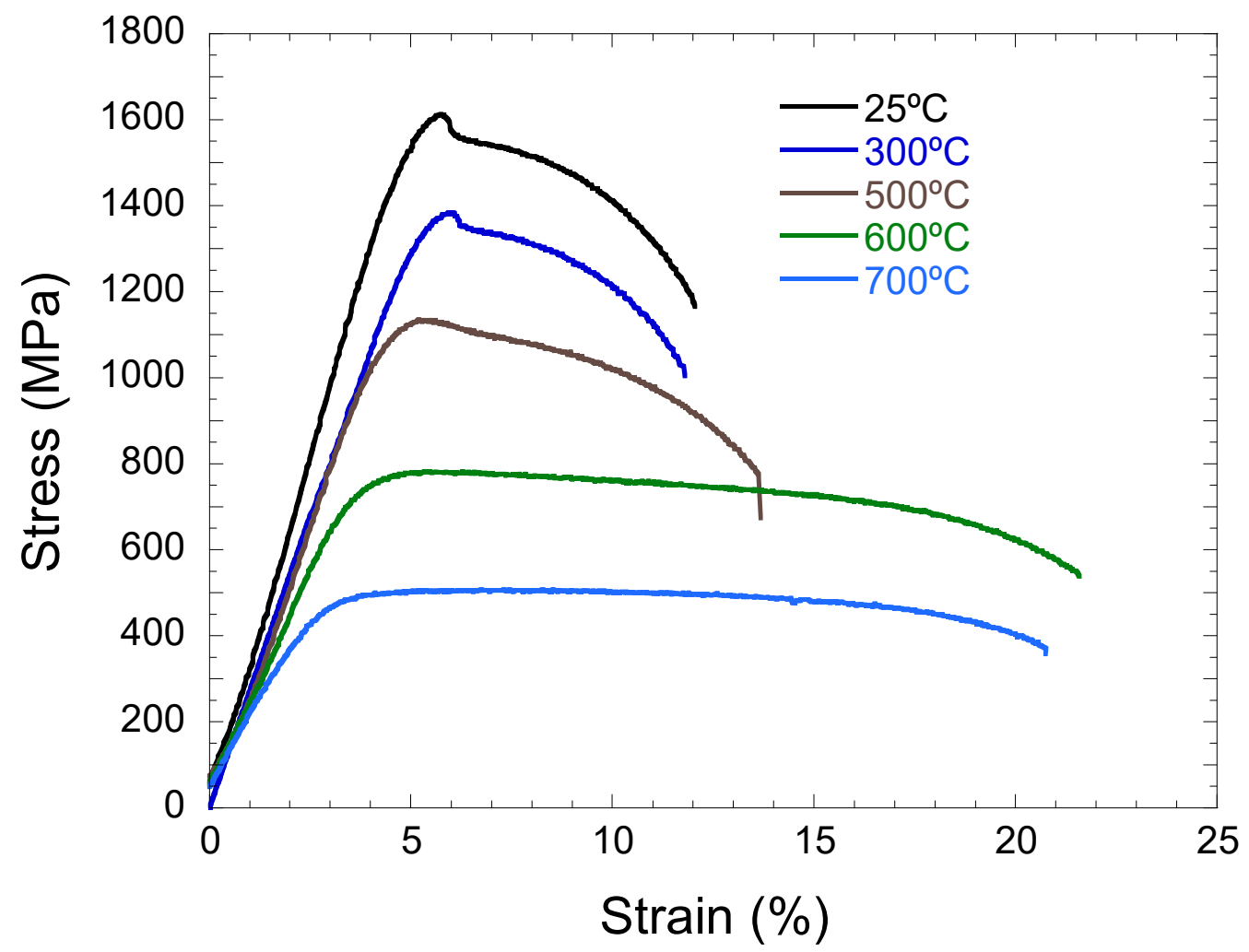

Figure 5. Stress-strain curves of $14 \mathrm{YWT}$-SM6 from $25^{\circ} \mathrm{C}$ to $700^{\circ} \mathrm{C}$. 


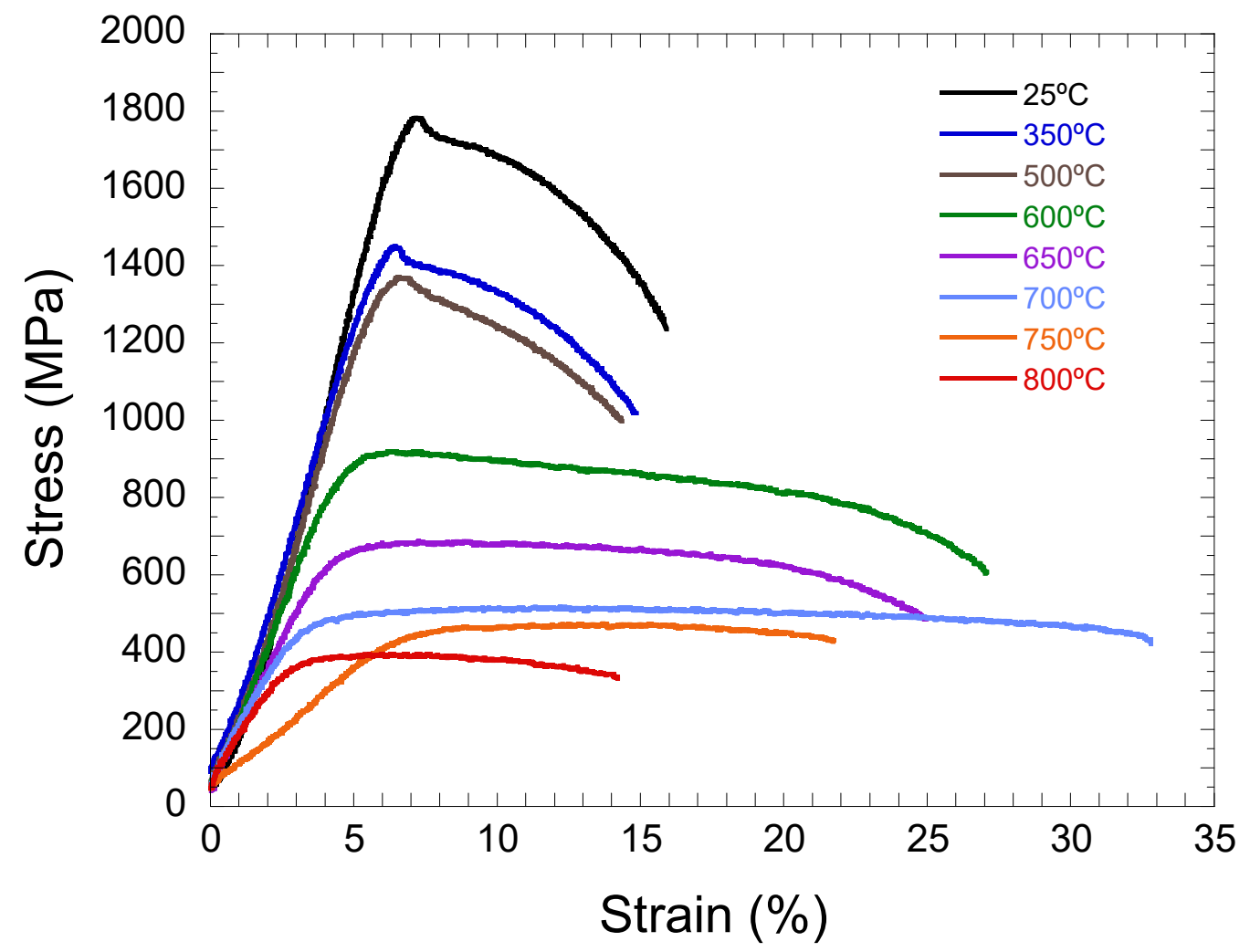

Figure 6. Stress-strain curves of $14 \mathrm{YWT}$-SM7 from $25^{\circ} \mathrm{C}$ to $800^{\circ} \mathrm{C}$.

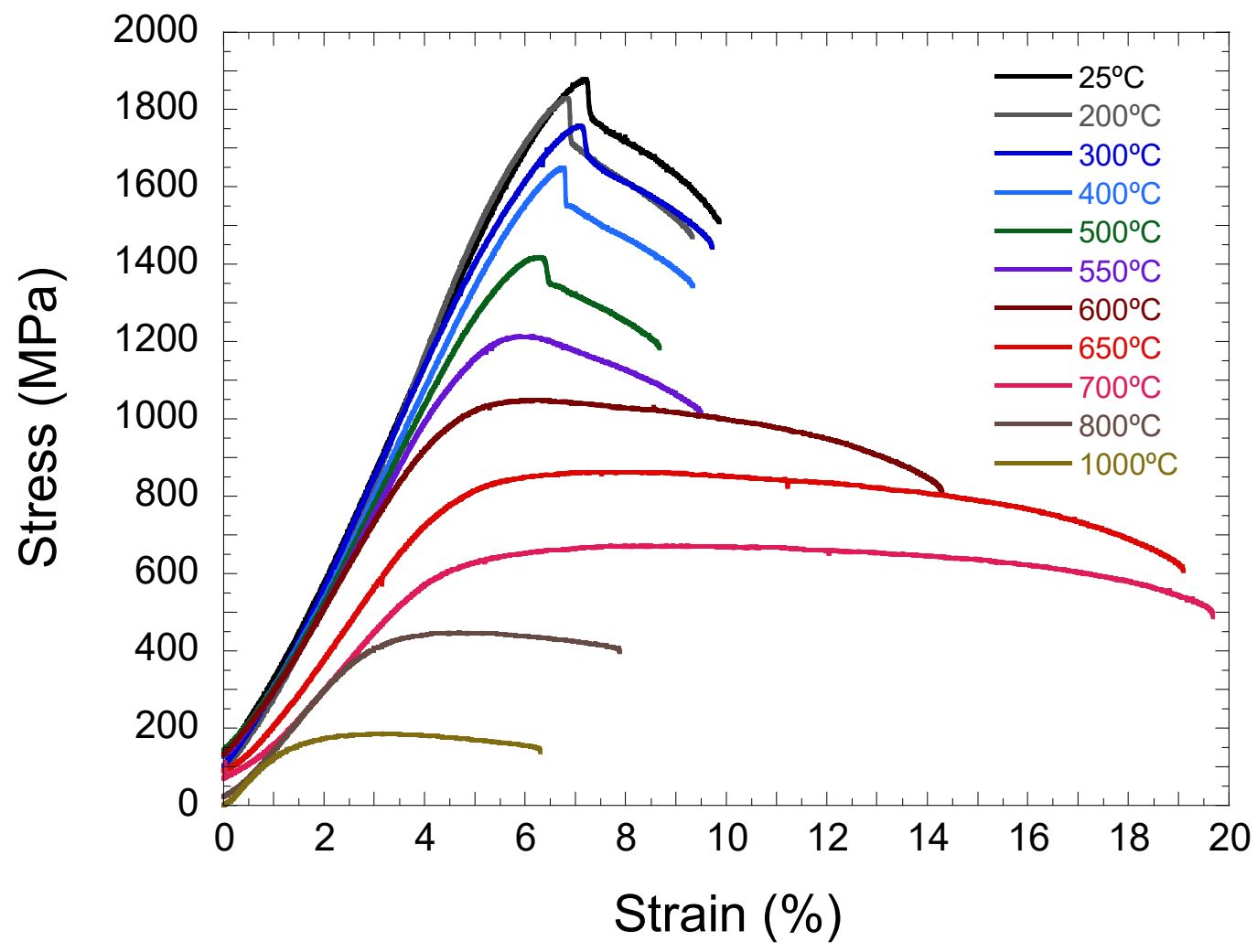

Figure 7. Stress-strain curves of $14 \mathrm{YWT}$-SM 10 from $25^{\circ} \mathrm{C}$ to $1000^{\circ} \mathrm{C}$. 


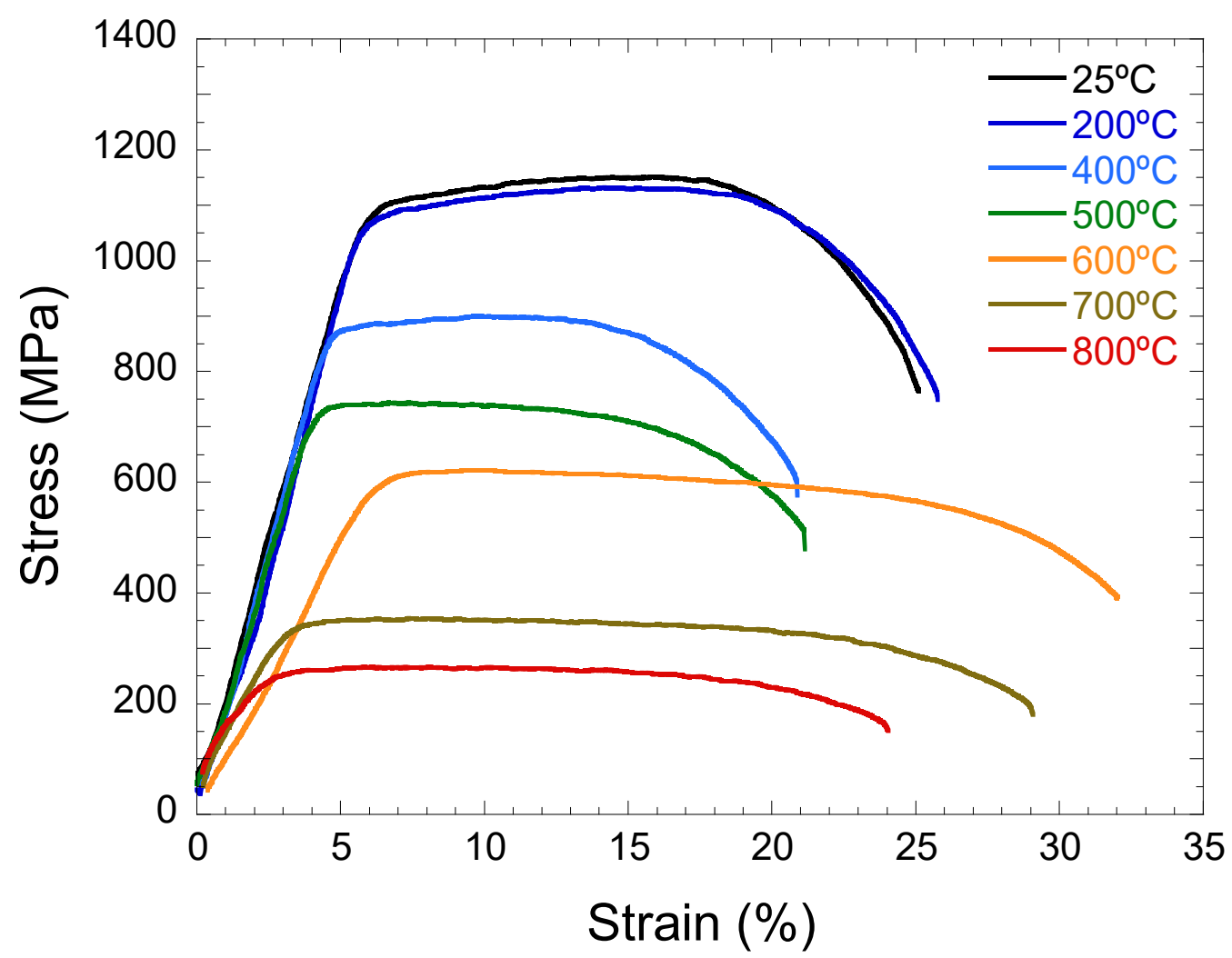

Figure 8. Stress-strain curves of $14 \mathrm{YWT}$-SM12a from $25^{\circ} \mathrm{C}$ to $800^{\circ} \mathrm{C}$.

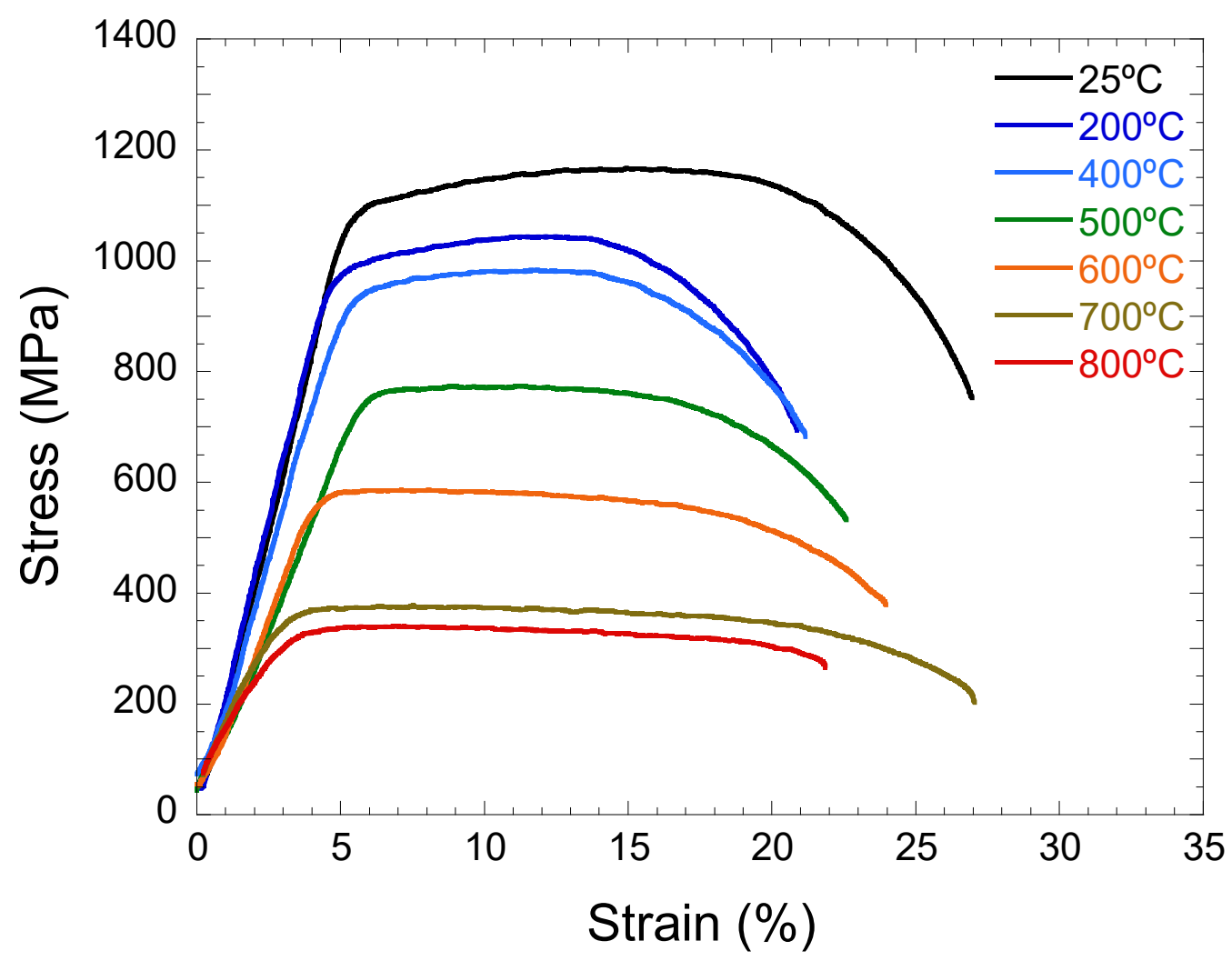

Figure 9. Stress-strain curves of $14 \mathrm{YWT}-\mathrm{SM} 12 \mathrm{c}$ from $25^{\circ} \mathrm{C}$ to $800^{\circ} \mathrm{C}$. 


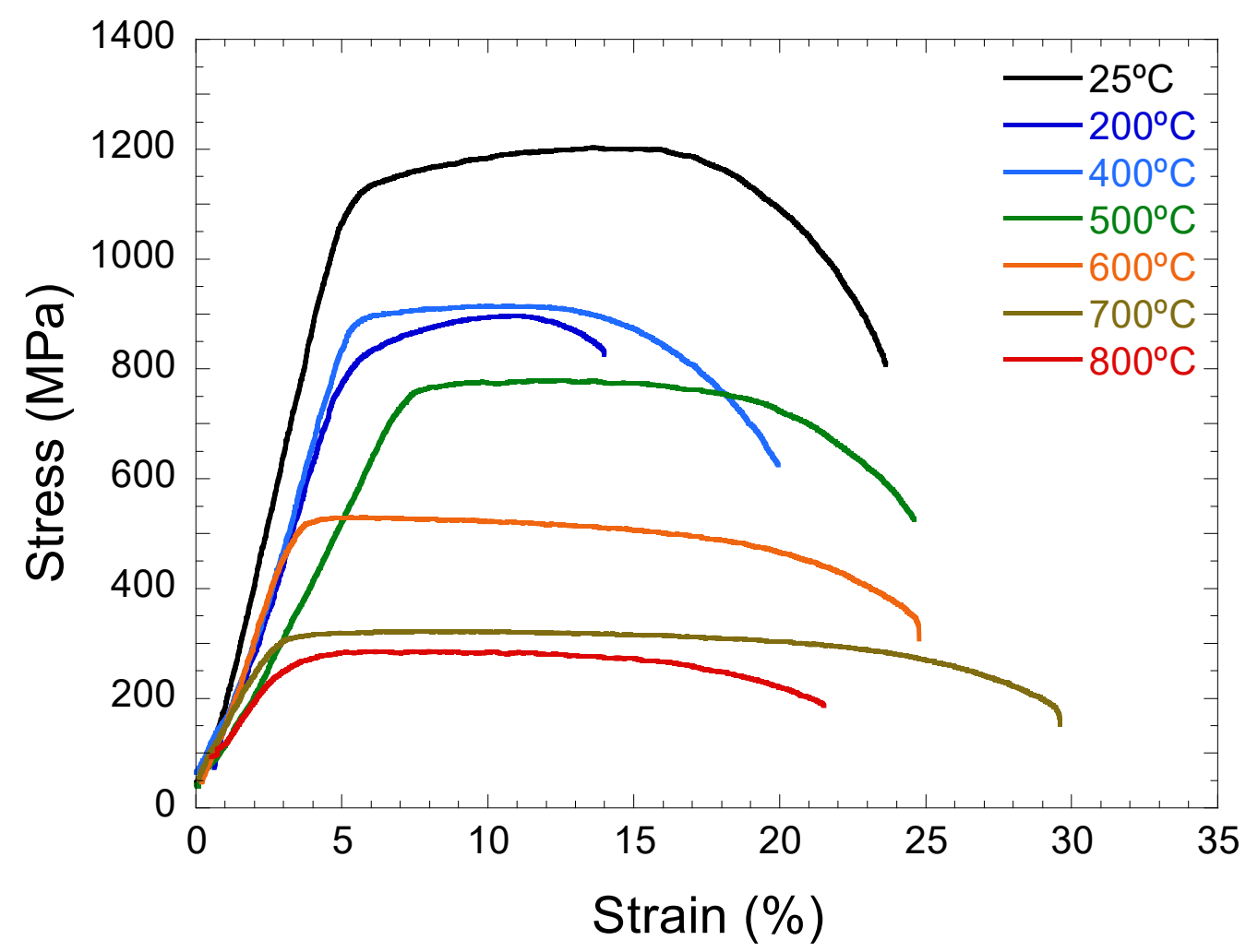

Figure 10. Stress-strain curves of $14 \mathrm{YWT}-\mathrm{SM} 12 \mathrm{~d}$ from $25^{\circ} \mathrm{C}$ to $800^{\circ} \mathrm{C}$.

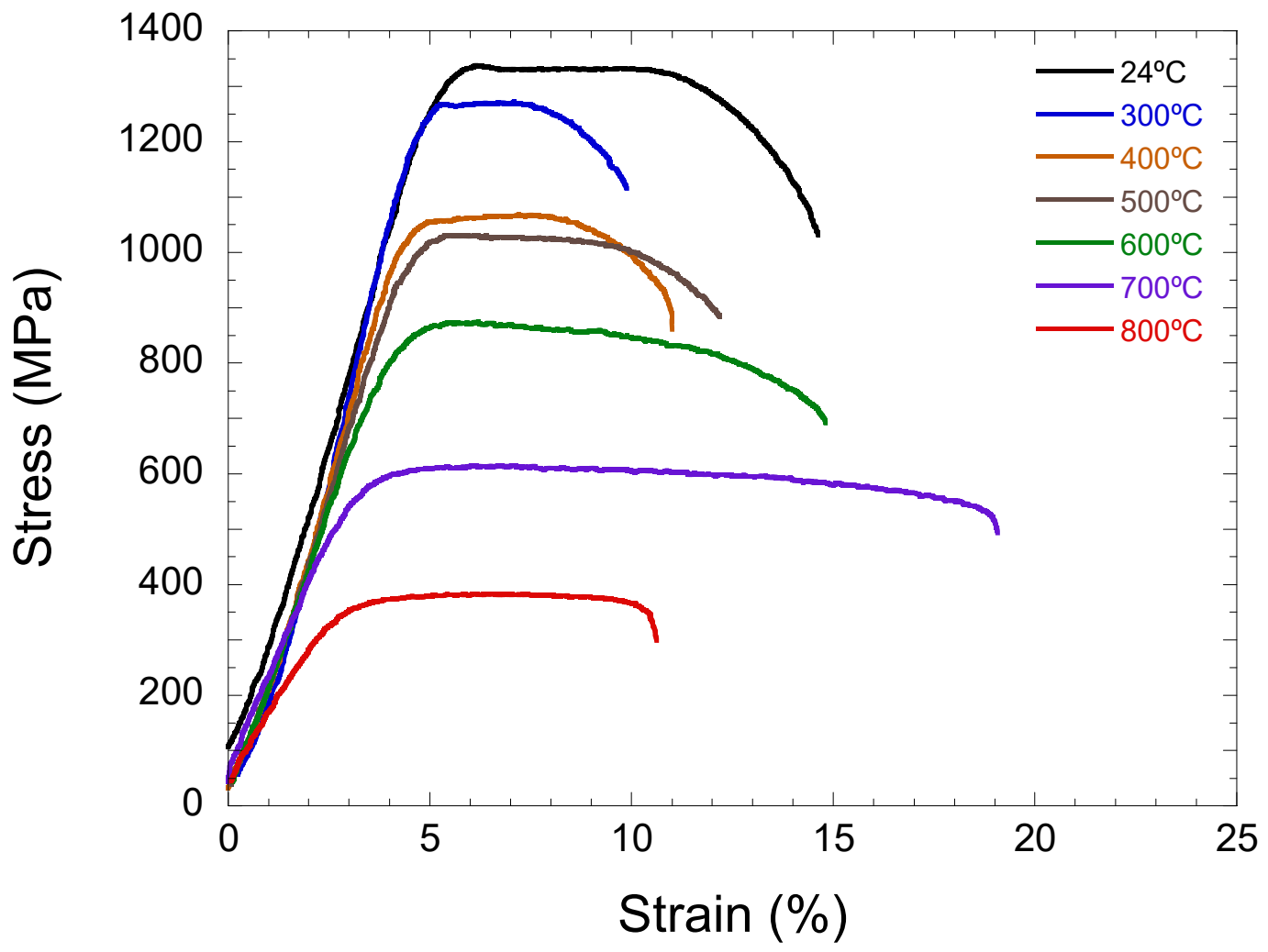

Figure 11. Stress-strain curves of $14 \mathrm{YWT}-\mathrm{SM} 13$ from $25^{\circ} \mathrm{C}$ to $800^{\circ} \mathrm{C}$. 


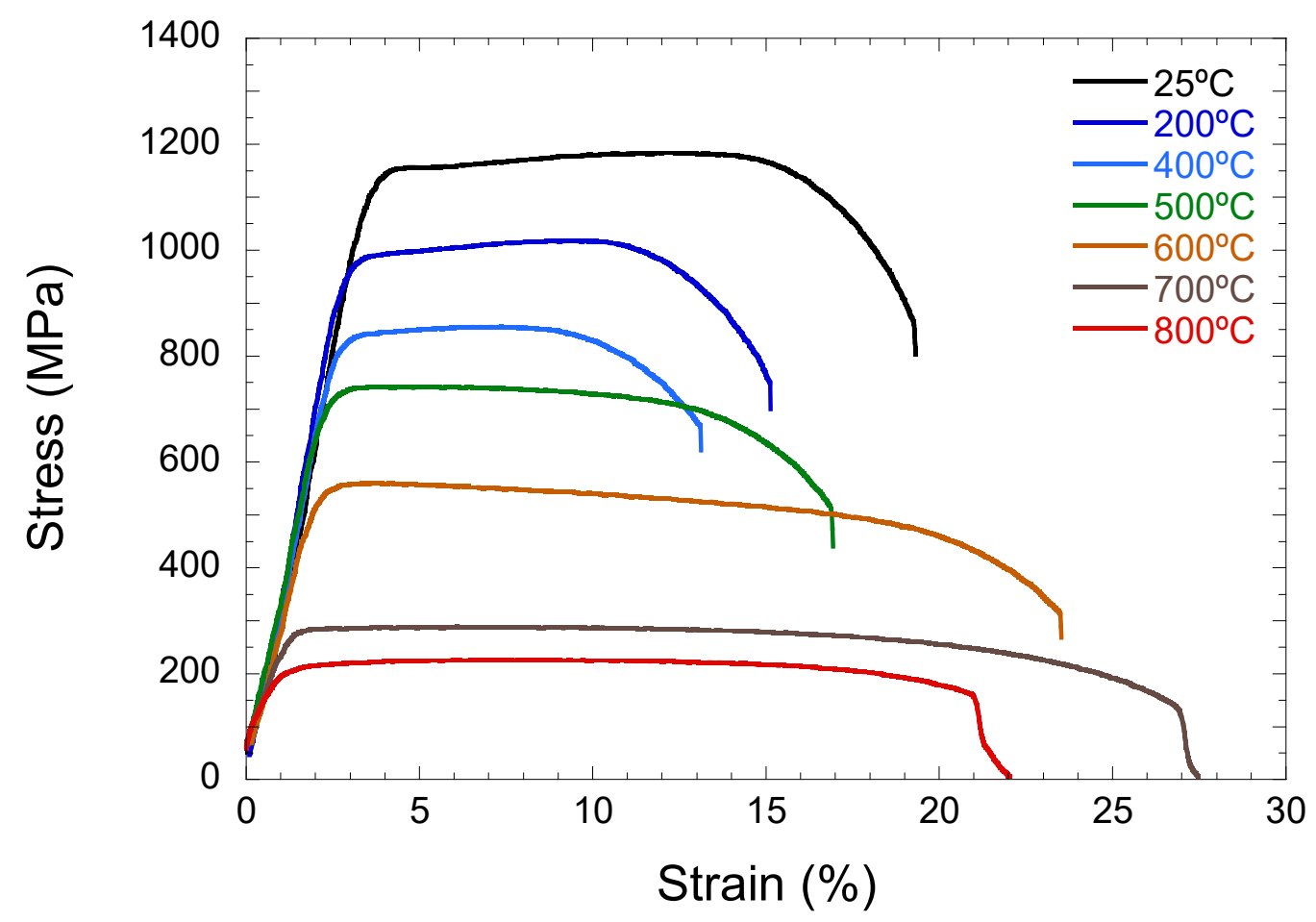

Figure 12. Stress-strain curves of $14 \mathrm{YWT}-\mathrm{NFA} 1$ from $25^{\circ} \mathrm{C}$ to $800^{\circ} \mathrm{C}$.

The tensile properties of the 14YWT heats were compiled from the stress-strain curves shown in Figures 2 to 12. Values of tensile property parameters were determined from these curves and Figure 13 compares the UTS (Fig. 13a) and TE (Fig. 13b) values as a function of test temperature from room temperature to $800^{\circ} \mathrm{C}$. Table 3 lists the YS, UTS, UE and TE values of the $14 \mathrm{YWT}$ heats at $25^{\circ} \mathrm{C}$ and Table 4 lists these values at $800^{\circ} \mathrm{C}$. Table 5 lists the YS, UTS, UE and TE for $14 \mathrm{YWT}-\mathrm{SM} 10$ at $800^{\circ} \mathrm{C}, 900^{\circ} \mathrm{C}$ and $1000^{\circ} \mathrm{C}$. Bar graphs of the YS, UTS, UE and TE values listed in Tables 3 and 4 are shown in Figure 14 (YS and UTS) and Figure 15 (UE and TE). The bar graphs shown if Figure 16 show the YS, UTS, UE and UT for 14 YWT-SM 10 from $800^{\circ} \mathrm{C}$ to $1000^{\circ} \mathrm{C}$.

In Figure 13, several trends are observed with the UTS (Fig. 13a) and TE (Fig. 13b) data of the 14YWT heats from $25^{\circ} \mathrm{C}$ to $800^{\circ} \mathrm{C}$. The high values of UTS vary over $\sim 700 \mathrm{MPa}$ at low temperatures. The UTS values decrease gradually from $25^{\circ} \mathrm{C}$ to $\sim 500^{\circ} \mathrm{C}$ and then decrease more rapidly between $500^{\circ} \mathrm{C}$ and $700^{\circ} \mathrm{C}$. With the exception of CR2, the range of UTS values decreases to $200 \mathrm{MPa}$ at 800 for the 14YWT heats. The TE data shows that the 14YWT heats with the lower strength properties have better ductility properties compared to the high strength 14YWT heats, such as SM10 which shows the lowest ductility. The TE values are fairly constant from $25^{\circ} \mathrm{C}$ to $500^{\circ} \mathrm{C}$, but then increase above $500^{\circ} \mathrm{C}$ to a peak near $650^{\circ} \mathrm{C}$ to $700^{\circ} \mathrm{C}$ before decreasing to lower values at $800^{\circ} \mathrm{C}$.

The bar graph plots shown in Figures 14 and 15 consist of the tensile properties that are listed in Tables 3 and 4 . These plots provide a clearer view of how the processing conditions of the 14YWT heats affected the strength and ductility properties. Figure 14 shows the YS and UTS data for the $14 \mathrm{YWT}$ heats at $25^{\circ} \mathrm{C}$ (Fig. 14a) and $800^{\circ} \mathrm{C}$ (Fig. 14b). At $25^{\circ} \mathrm{C}$, the early generation of 14 YWT heats, except CR2, have much higher YS and UTS than the more recent generation of 14YWT heats that were produced with improve mechanical alloying conditions that led to lower $\mathrm{O}, \mathrm{N}$ and $\mathrm{C}$ contamination levels. This trend becomes less obvious at $800^{\circ} \mathrm{C}$. Although SM7 and SM10 still maintain the highest strengths, SM12c and SM13 possessed good strengths at $800^{\circ} \mathrm{C}$. The processing condition for SM12c consisted of an initial anneal of the ball milled $\mathrm{Fe}$-alloyed and $\mathrm{Y}_{2} \mathrm{O}_{3}$ powders at $850^{\circ} \mathrm{C}$ followed by extrusion at $1000^{\circ} \mathrm{C}$ [7]. For SM13, the 
oxygen level was elevated slightly by ball milling $\mathrm{FeO}$ powder with the Fe-alloyed and $\mathrm{Y}_{2} \mathrm{O}_{3}$ powders. The TE data shown in Figure 15 shows that the early generation heats of CR4 and SM4 and the recent generation of heats (SM12, SM13 and NFA1) high strength heats have much higher values compared to the high strength heats of SM7 and SM10 (SM6 at $25^{\circ} \mathrm{C}$ ) at both $25^{\circ} \mathrm{C}$ and $800^{\circ} \mathrm{C}$. The UE data of the $14 \mathrm{YWT}$ heats shows a similar trend with the TE data. At $25^{\circ} \mathrm{C}$, the UE for the early generation CR4 and recent generation SM12, SM13 and NFA1 is much higher than for the high strength heats of SM7 and SM10.

The bar graphs shown in Figure 16 for 14YWT-SM10 represent the only data that was obtained from tensile tests above $800 \mathrm{C}$. Figure 16a shows YS and UTS decreasing from $\sim 400 \mathrm{MPa}$ and $\sim 430 \mathrm{MPa}$, respectively, at $800^{\circ} \mathrm{C}$ to $\sim 130 \mathrm{MPa}$ and $\sim 170 \mathrm{MPa}$ at $1000^{\circ} \mathrm{C}$, respectively. Although the UE and TE values are low for the SM10 heat, Figure $16 \mathrm{~b}$ shows that both $\mathrm{UE}$ and TE remain fairly constant from $800^{\circ} \mathrm{C}$ to $1000^{\circ} \mathrm{C}$. The reason for the drop in $\mathrm{TE}$ at $900^{\circ} \mathrm{C}$ is unclear but is consistent with the overall low ductility of SM10 even at high temperatures.

In summary, the extensive set of tensile data obtained from several heats of $14 \mathrm{YWT}$ from $25^{\circ} \mathrm{C}$ to $800^{\circ} \mathrm{C}$ provides an understanding of what processing conditions lead to the best balance between high strength and high ductility over the full operating temperature range. 
(a)

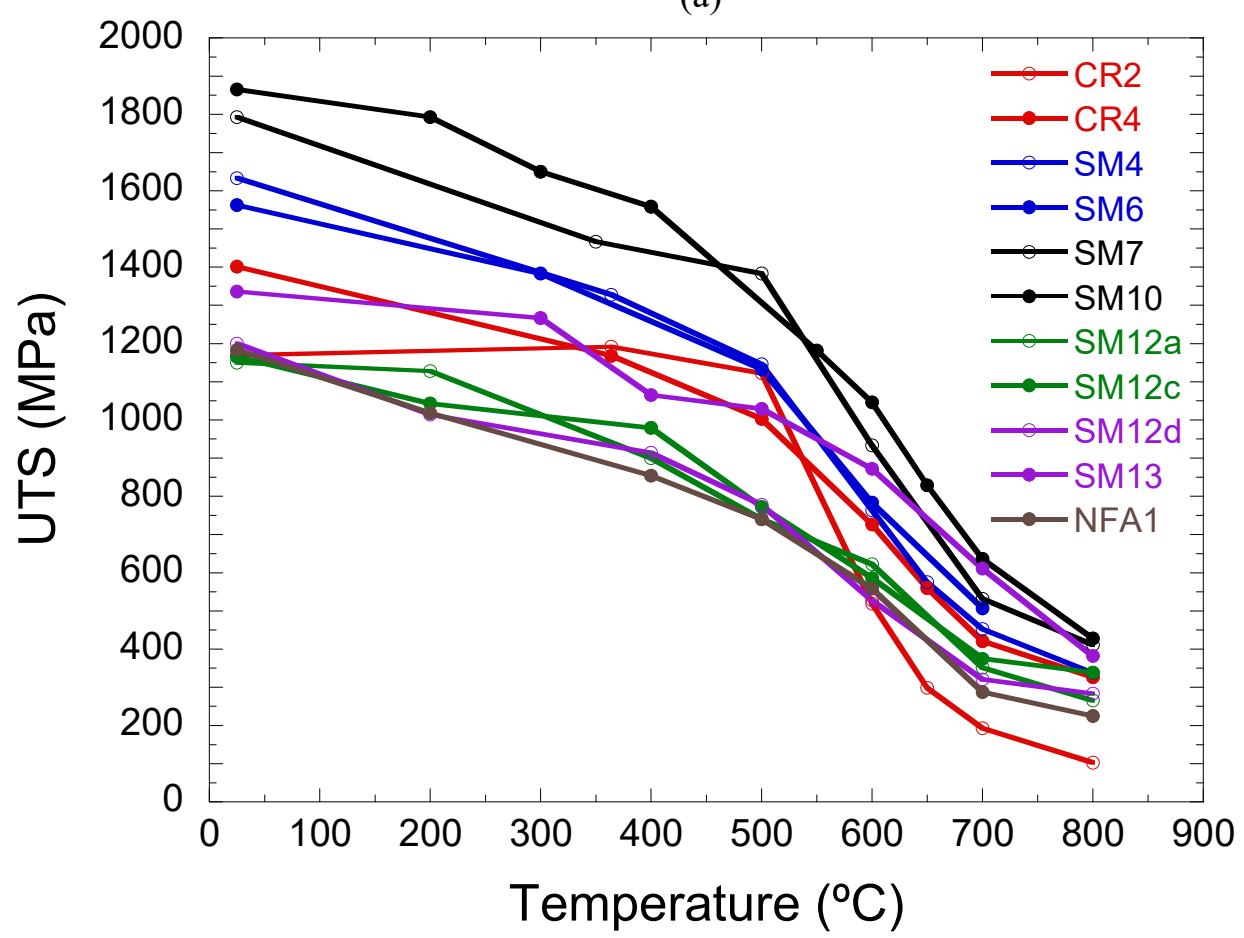

(b)

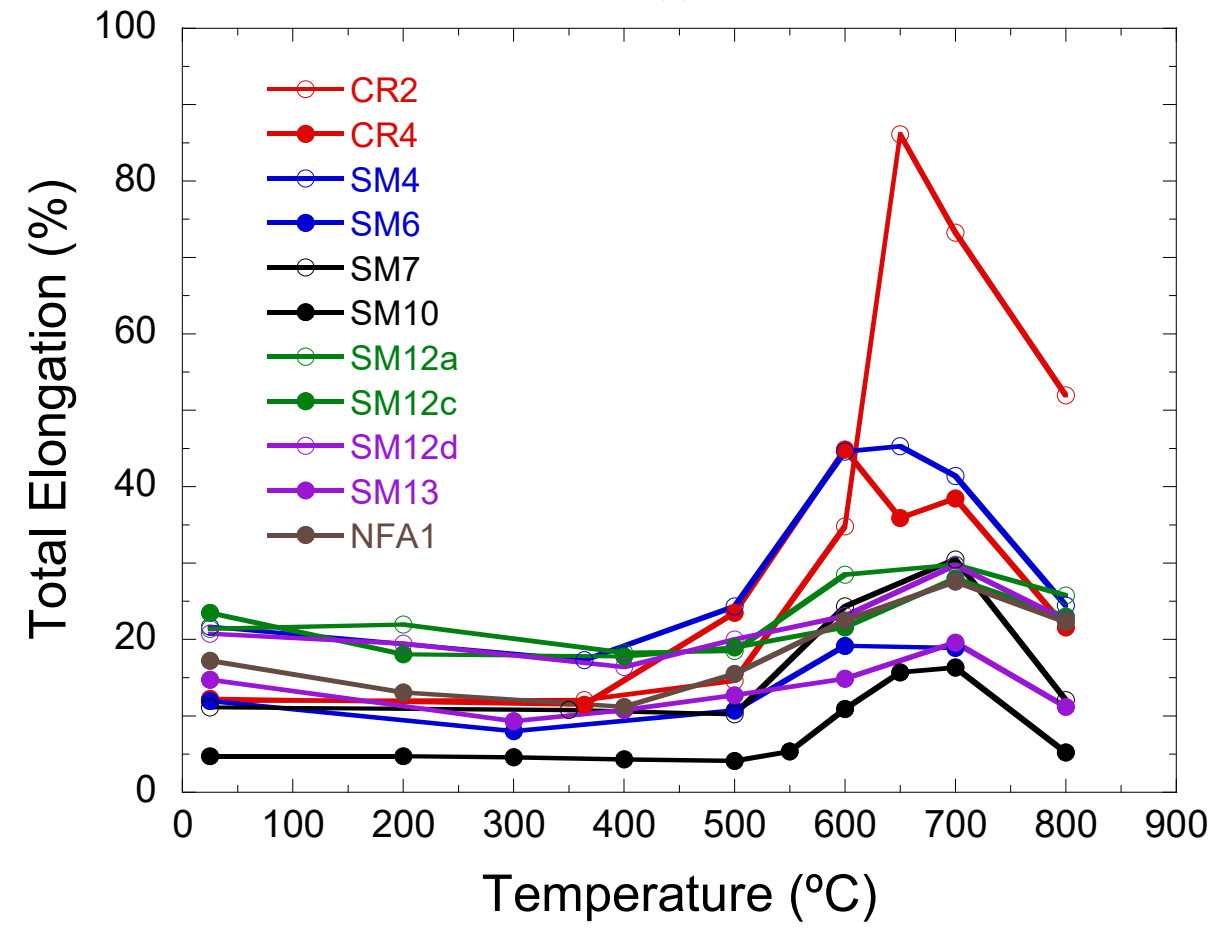

Figure 13. Comparison of (a) ultimate tensile strength and (b) total elongation from $25^{\circ} \mathrm{C}$ to $800^{\circ} \mathrm{C}$ for the 14YWT heats. 
Table 3. Comparison of tensile properties of 14YWT heats at $25^{\circ} \mathrm{C}$.

\begin{tabular}{|c|c|c|c|c|}
\hline Heat & $\begin{array}{c}\text { YS } \\
(\mathrm{MPa})\end{array}$ & $\begin{array}{c}\text { UTS } \\
(\mathrm{MPa})\end{array}$ & $\begin{array}{c}\text { UE } \\
(\%)\end{array}$ & $\begin{array}{c}\text { TE } \\
(\%)\end{array}$ \\
\hline CR2 & 802 & 1169 & 7.0 & 12.0 \\
\hline CR4 & 1256 & 1402 & 7.7 & 23.2 \\
\hline SM4 & 1465 & 1634 & 2.1 & 21.7 \\
\hline SM6 & 1435 & 1564 & 0.8 & 12.0 \\
\hline SM7 & 1587 & 1792 & 0.9 & 11.1 \\
\hline SM10 & 1600 & 1866 & 0.7 & 4.7 \\
\hline SM12a & 1059 & 1151 & 10.3 & 21.4 \\
\hline SM12c & 1069 & 1165 & 8.1 & 23.5 \\
\hline SM12d & 1078 & 1201 & 7.6 & 20.8 \\
\hline SM13 & 1276 & 1336 & 6.3 & 14.7 \\
\hline NFA-1 & 1079 & 1183 & 8.5 & 17.2 \\
\hline
\end{tabular}

Table 4. Comparison of tensile properties of $14 \mathrm{YWT}$ heats at $800^{\circ} \mathrm{C}$.

\begin{tabular}{|c|c|c|c|c|}
\hline Heat & $\begin{array}{c}\text { YS } \\
(\mathrm{MPa})\end{array}$ & $\begin{array}{c}\text { UTS } \\
(\mathrm{MPa})\end{array}$ & $\begin{array}{c}\text { UE } \\
(\%)\end{array}$ & $\begin{array}{c}\text { TE } \\
(\%)\end{array}$ \\
\hline CR2 & 65 & 103 & 10.9 & 52.0 \\
\hline CR4 & 269 & 327 & 4.0 & 21.6 \\
\hline SM4 & 288 & 337 & 6.4 & 24.5 \\
\hline SM7 & 323 & 412 & 5.6 & 12.1 \\
\hline SM10 & 395 & 429 & 1.5 & 5.2 \\
\hline SM12a & 245 & 266 & 3.0 & 25.8 \\
\hline SM12c & 308 & 339 & 4.5 & 23.0 \\
\hline SM12d & 247 & 284 & 6.0 & 22.6 \\
\hline SM13 & 339 & 382 & 6.4 & 11.2 \\
\hline NFA-1 & 202 & 226 & 6.8 & 22.3 \\
\hline
\end{tabular}

Table 5. Tensile properties of 14YWT-SM10 at 800,900 and $1000^{\circ} \mathrm{C}$.

\begin{tabular}{|c|c|c|c|c|}
\hline Heat & $\begin{array}{c}\text { YS } \\
(\mathrm{MPa})\end{array}$ & $\begin{array}{c}\text { UTS } \\
(\mathrm{MPa})\end{array}$ & $\begin{array}{c}\text { UE } \\
(\%)\end{array}$ & $\begin{array}{c}\text { TE } \\
(\%)\end{array}$ \\
\hline 800 & 395 & 429 & 1.5 & 5.2 \\
\hline 900 & 232 & - & - & - \\
\hline 1000 & 117 & 184 & 1.9 & 5.3 \\
\hline
\end{tabular}


(a)

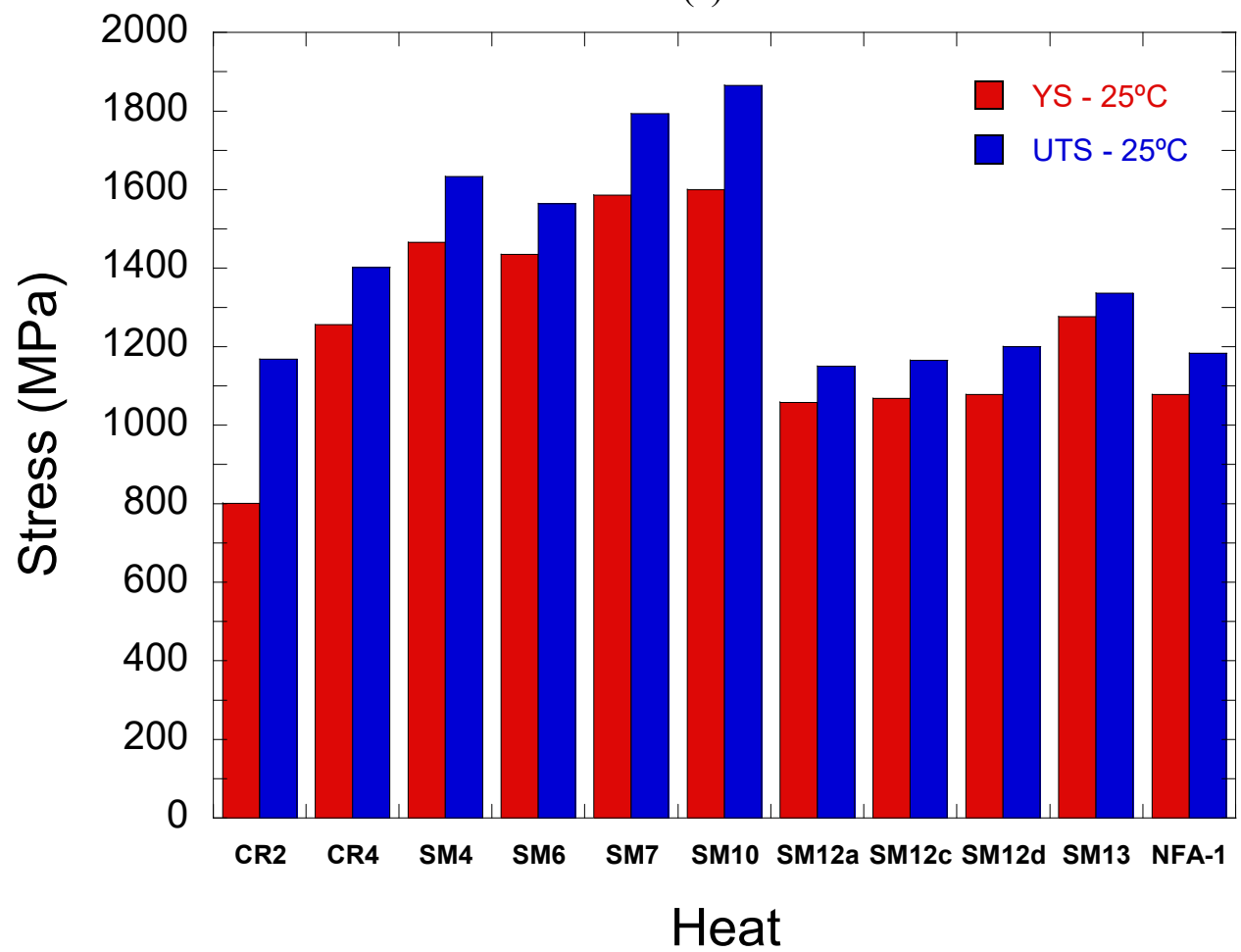

(b)

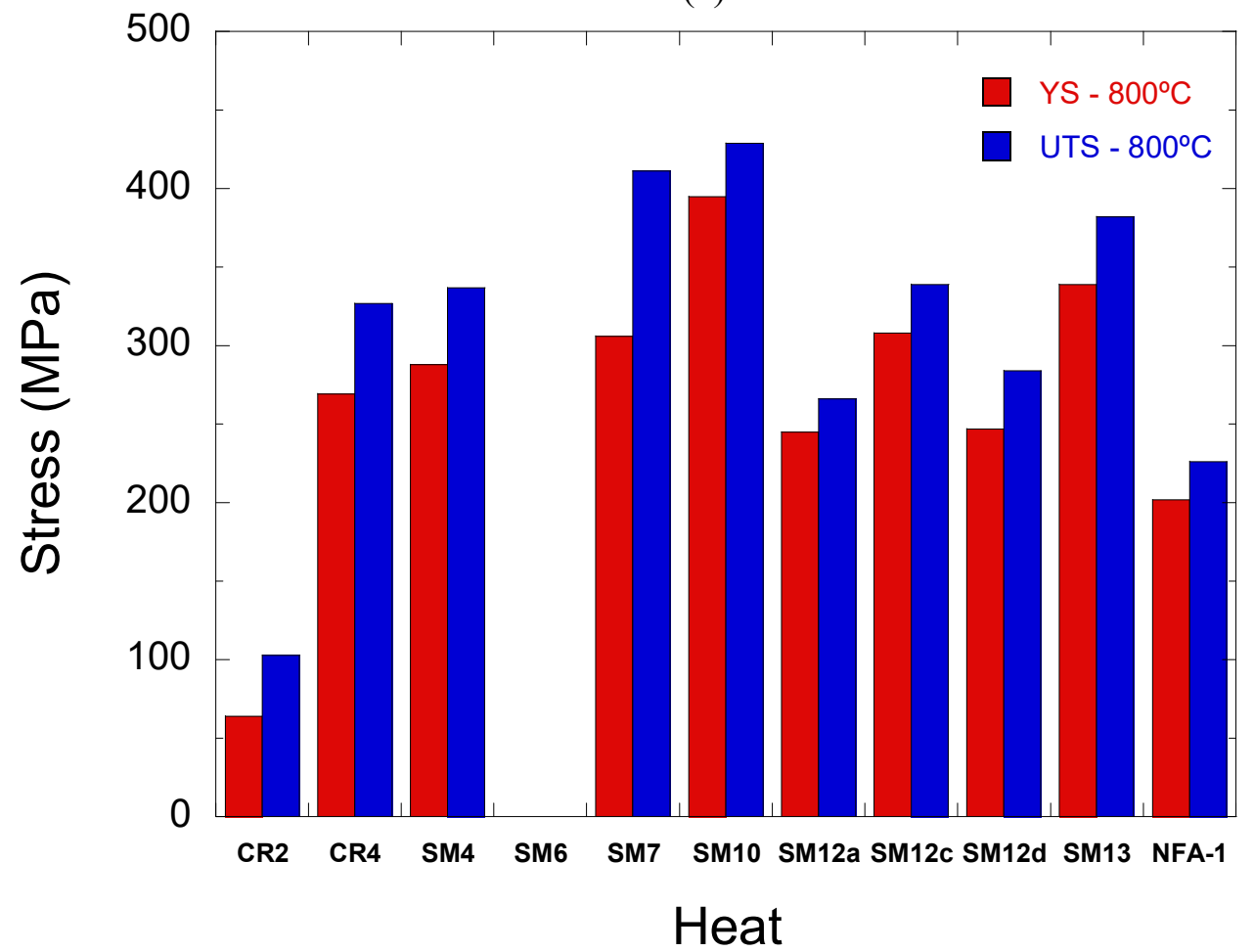

Figure 14. Bar graphs comparing the yield stress and ultimate tensile stress of the 14YWT heats at (a) $25^{\circ} \mathrm{C}$ and (b) $800^{\circ} \mathrm{C}$. 
(a)

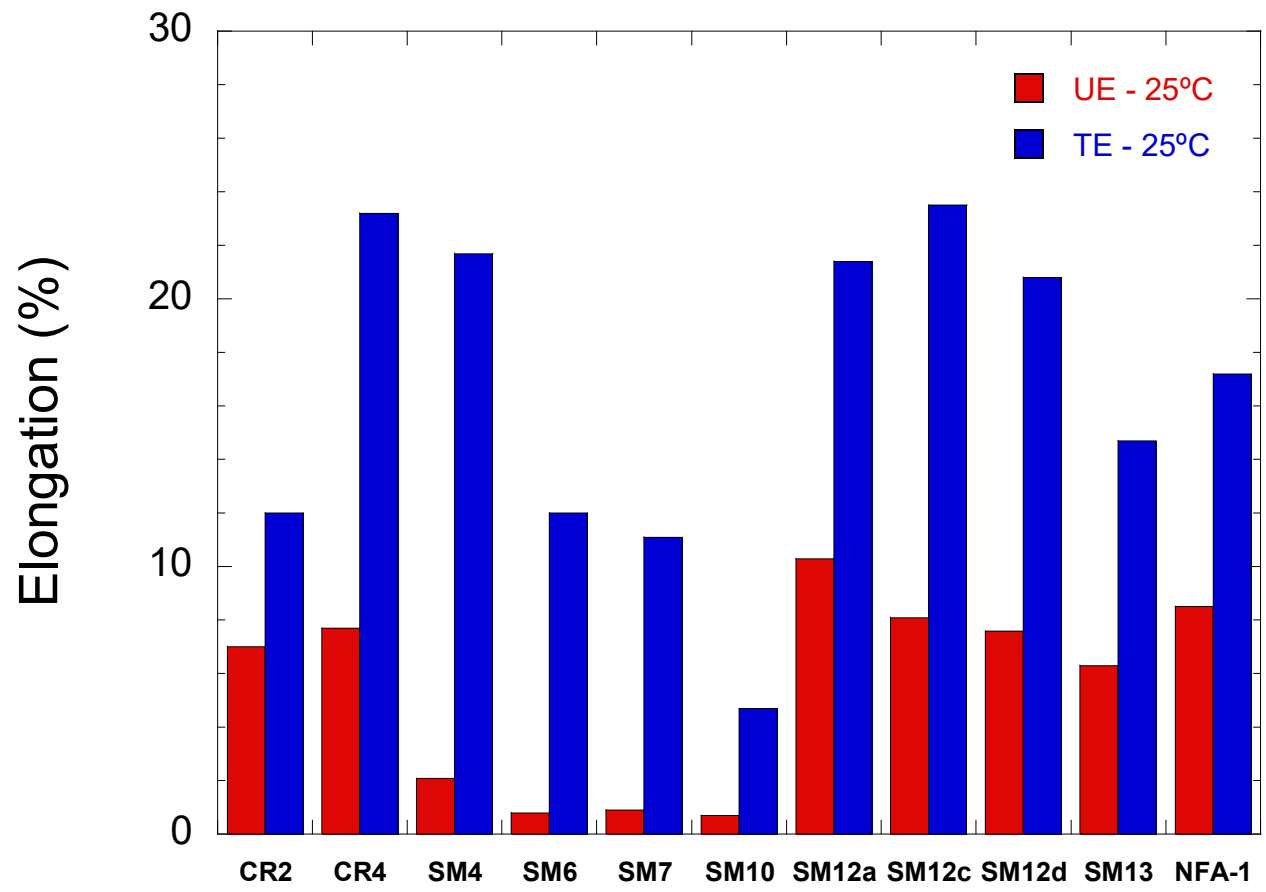

Heat

(b)

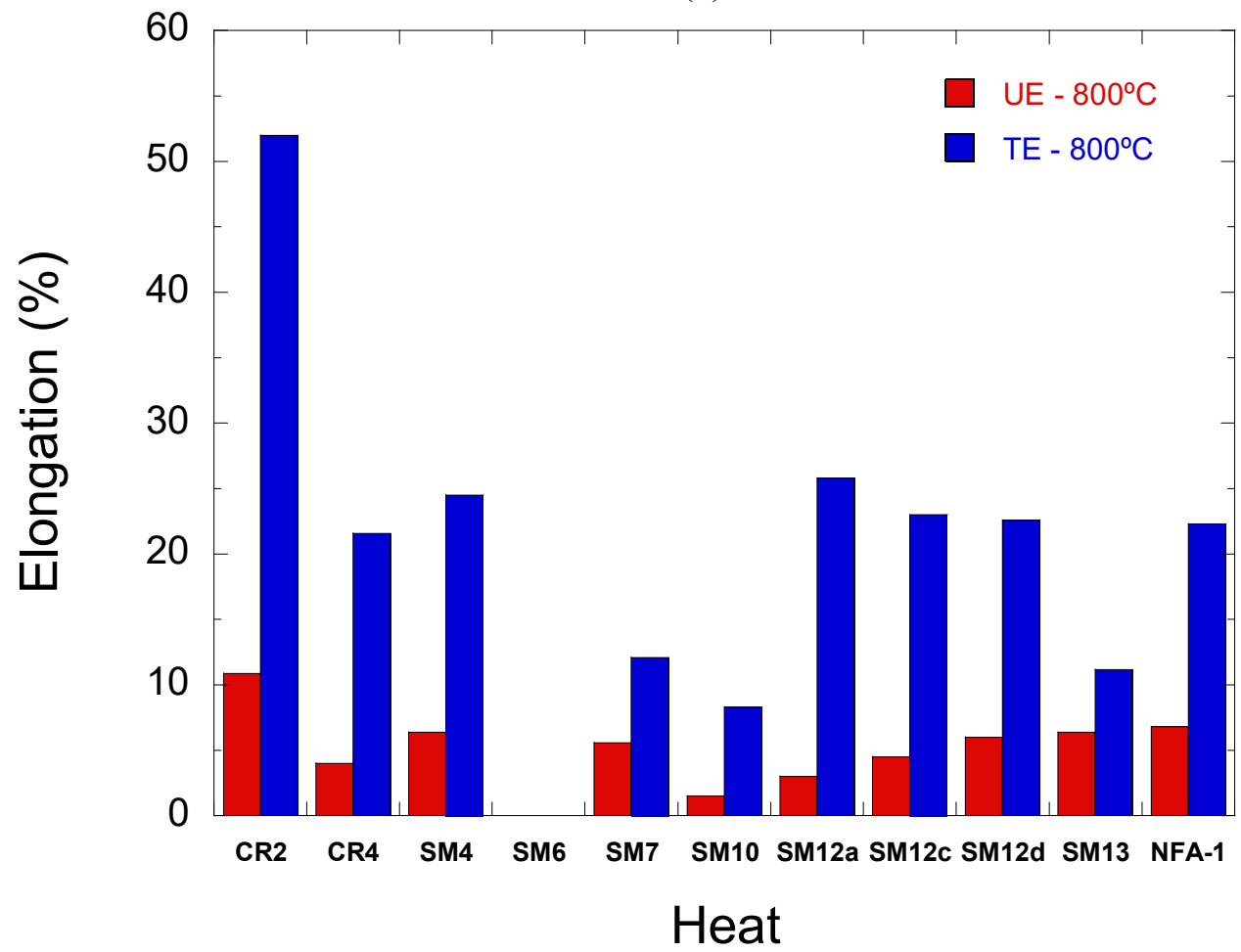

Figure 15. Bar graphs comparing the uniform and total elongations of the $14 \mathrm{YWT}$ heats at (a) $25^{\circ} \mathrm{C}$ and (b) $800^{\circ} \mathrm{C}$. 
(a)

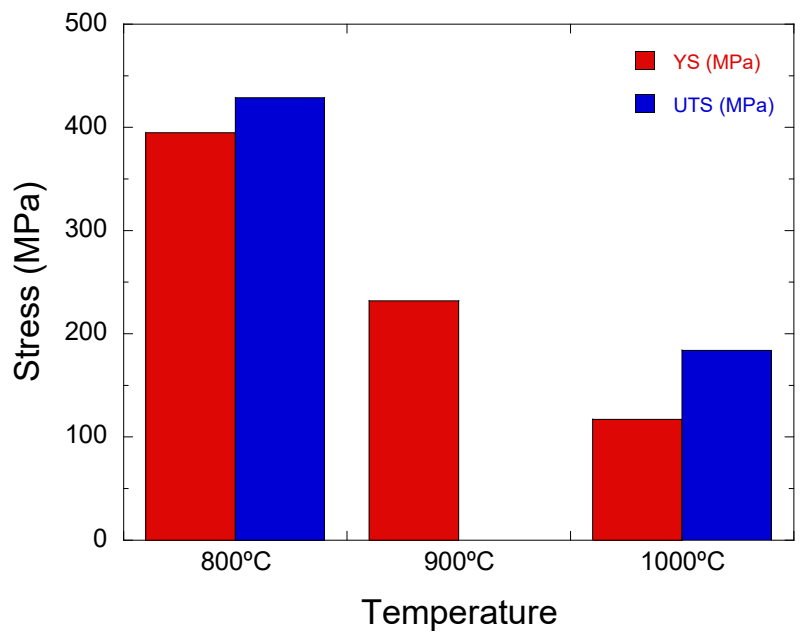

(b)

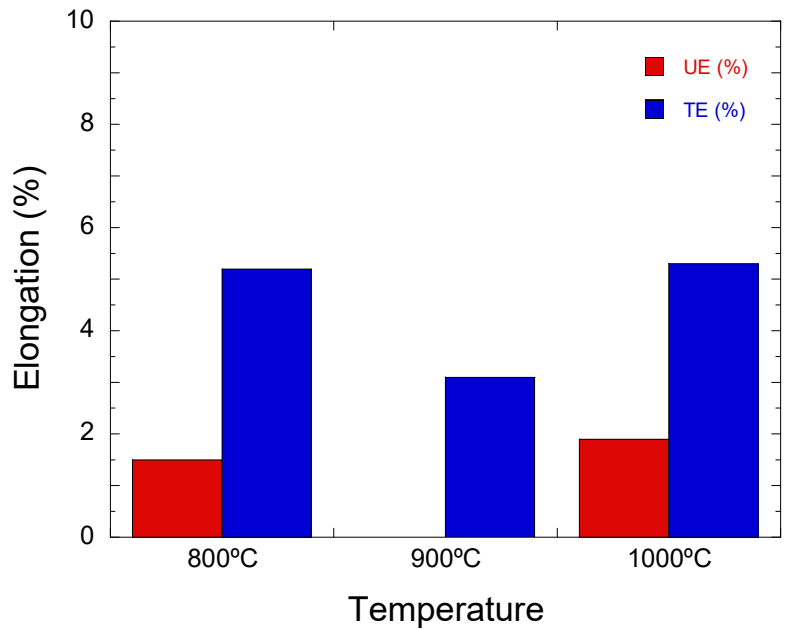

Figure 16. Bar graphs of the (a) yield stress and ultimate tensile stress and (b) uniform and total elongations of $14 \mathrm{YWT}-\mathrm{SM} 10$ at $800^{\circ} \mathrm{C}, 900^{\circ} \mathrm{C}$ and $1000^{\circ} \mathrm{C}$.

\subsection{OFRAC}

Tensile tests were conducted on OFRAC using SS-3 type specimens (Figure 1). Stress-strain curves were obtained from room temperature $\left(25^{\circ} \mathrm{C}\right)$ to $800^{\circ} \mathrm{C}$ in air using a nominal strain rate of $1 \times 10^{-3} \mathrm{~s}^{-1}$, which are the same test conditions that were used on the 14YWT heats. The tensile curves from $25^{\circ} \mathrm{C}$ to $800^{\circ} \mathrm{C}$ are shown in Figure 17. The results show similar levels of strength and ductility over the temperature range as that of the new generation of 14YWT heats (Fig.'s 8-12) produced with improved mechanical alloying conditions.

In the collaboration between ORNL and NFD, the contract required the Vickers hardness of OFRAC to be $350 \mathrm{VH}$ or lower for fabricating the thin wall tubing by pilger rolling at room temperature. To obtain this hardness level, samples were fabricated from the extruded bar and annealed in vacuum $\left(7 \times 10^{-5} \mathrm{mbar}\right)$ for $8 \mathrm{~h}$ at $1050^{\circ} \mathrm{C}$ and $1150^{\circ} \mathrm{C}$. A hardness value of $350 \mathrm{VH}$ was obtained from after annealing for $8 \mathrm{~h}$ at $1150^{\circ} \mathrm{C}$. Tensile tests were conducted on SS-3 specimens fabricated from samples exposed to both annealing conditions over the temperatures from $25^{\circ} \mathrm{C}$ to $800^{\circ} \mathrm{C}$. Figure 18 shows the changes in YS and UTS (Fig. 18a) and UE and TE (Fig. 18b) with temperature. The YS decreases by $\sim 100 \mathrm{MPa}$ at $25^{\circ} \mathrm{C}$ after the $1150^{\circ} \mathrm{C}$ annealing but both YS and UTS show minor variations over most of the temperature range. The UE properties of the two annealed conditions followed a similar trend of being lower than that of the extruded condition over the temperature range. The UE of both annealed conditions started to decrease above $\sim 200^{\circ} \mathrm{C}$ to lower values. The TE properties of all three conditions were similar up to $\sim 400^{\circ} \mathrm{C}$ and then increased to higher values. The TE of the extruded and $1050^{\circ} \mathrm{C}$ annealed conditions peaked around $600^{\circ} \mathrm{C}$ to $700^{\circ} \mathrm{C}$ while that of the $1150^{\circ} \mathrm{C}$ annealed condition showed a linear increase to $800^{\circ} \mathrm{C}$. Overall, the tensile results suggest that the strengthening contributions in the microstructure of OFRAC in the extruded condition is thermally stable for $8 \mathrm{~h}$ at temperatures as high as $1150^{\circ} \mathrm{C}(\sim 0.80 \mathrm{TM}$, where $\mathrm{TM}$ is the absolute melting temperature). 


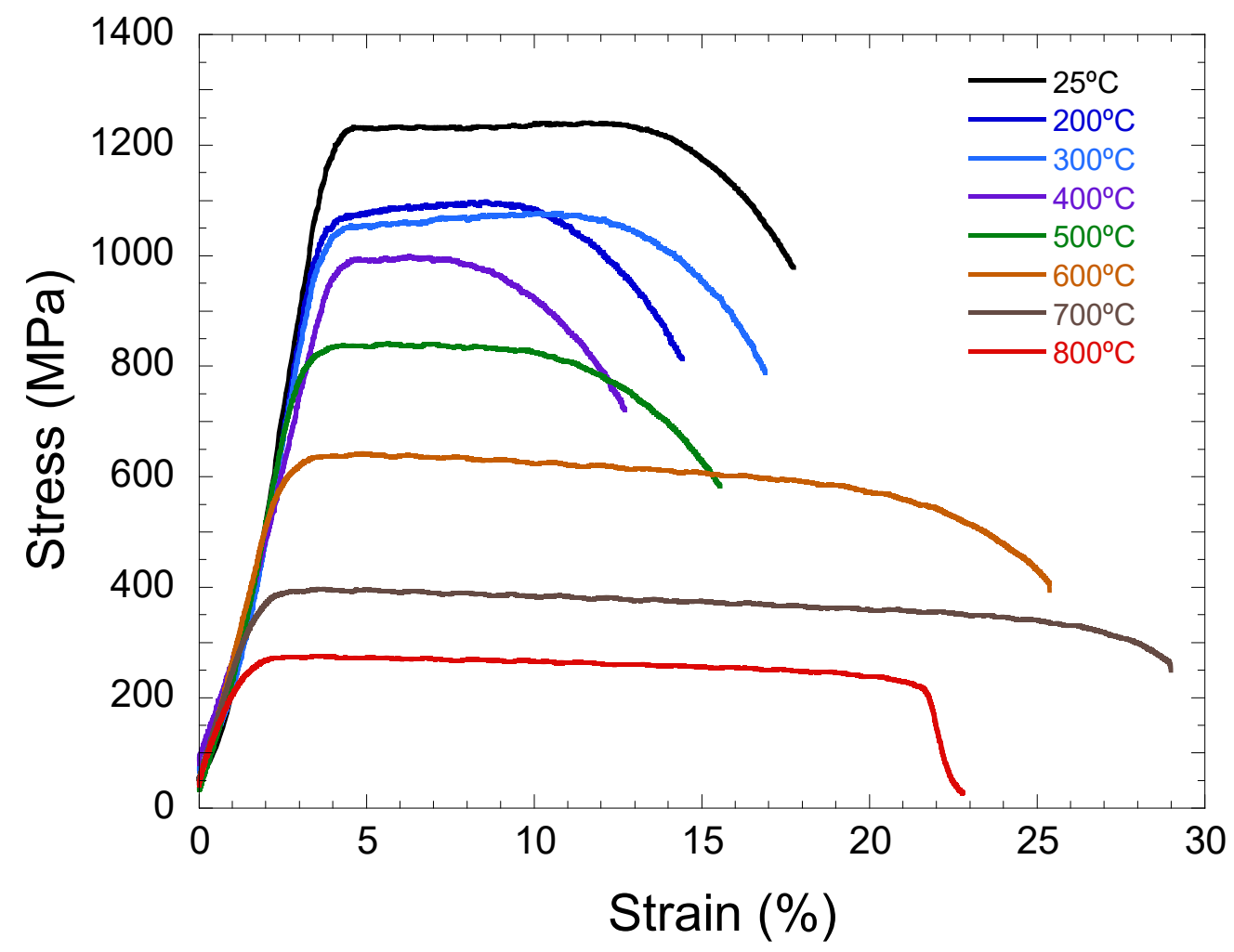

Figure 17. Stress-strain curves of OFRAC from $25^{\circ} \mathrm{C}$ to $800^{\circ} \mathrm{C}$.

(a)

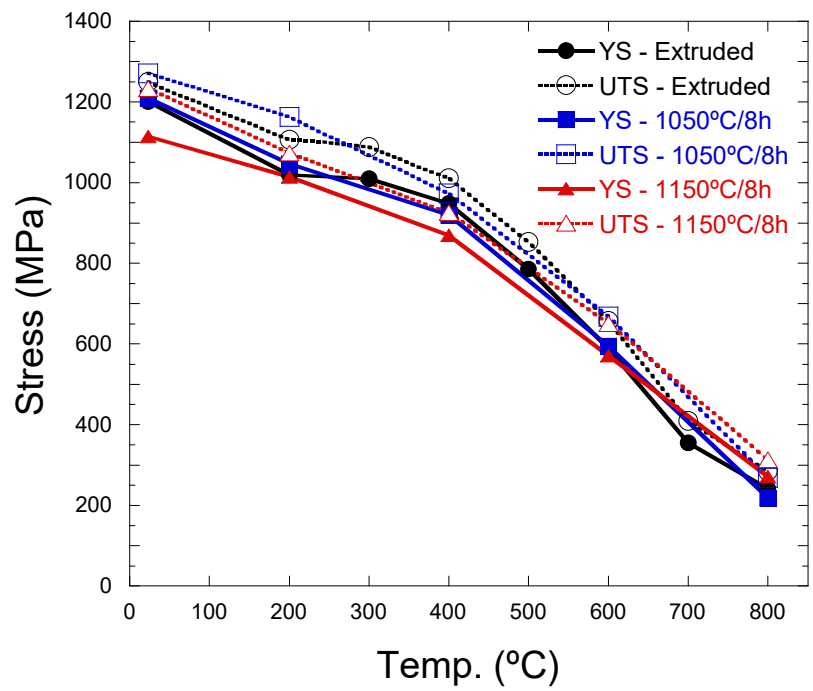

(b)

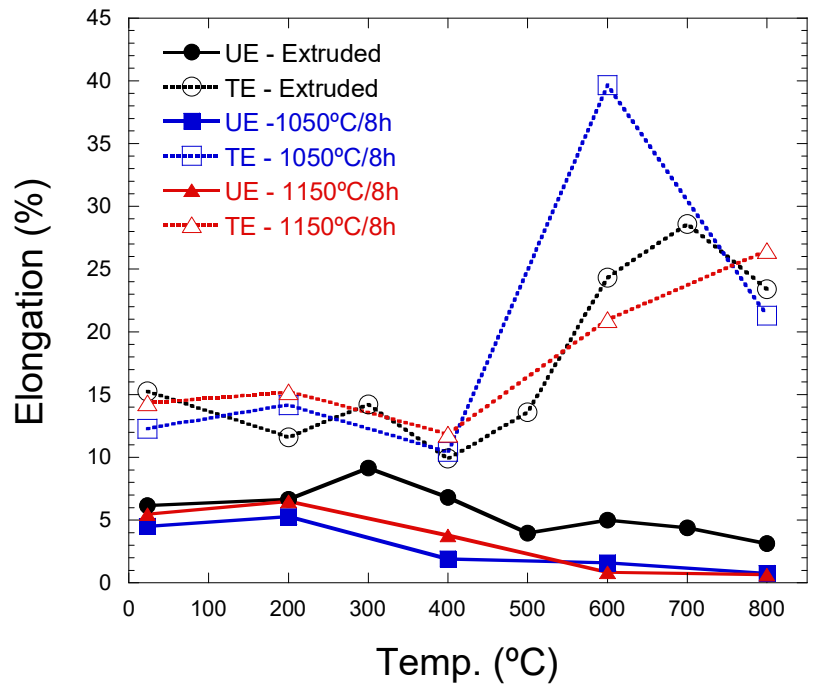

Figure 18. Comparison of (a) YS and UTS and (b) UE and TE from $25^{\circ} \mathrm{C}$ to $800^{\circ} \mathrm{C}$ for OFRAC in the extruded condition and after annealing for $8 \mathrm{~h}$ at $1050^{\circ} \mathrm{C}$ and $1150^{\circ} \mathrm{C}$. 


\section{CREEP RESULTS}

Limited thermal creep data exists for 14YWT and OFRAC. Two time to failure creep studies were conducted the SM10 heat of 14YWT. While OFRAC is a recently developed NFA, the creep data was obtained from strain rate jump tests at elevated temperatures.

\subsubsection{YWT}

The creep studies conducted on 14YWT-SM10 used two types of specimens based on the type of creep test that was performed. Figure 19 shows the dimensions of the two types of creep specimens. The 1.65 in long cylindrical specimen design shown in Figure 19a consists of threaded grips, extensometer grooves and gage that was 0.4 in long and 0.113 in diameter. Three of these specimens were fabricated and tested using an MTS test frame in constant stress control with applied stresses of 300,250 and $200 \mathrm{MPa}$ at $800^{\circ} \mathrm{C}$. The 3.0 in long cylindrical specimen design shown in Figure 19b consisted of threaded grips, extensometer grooves and gage that was 0.8 in long and 0.198 in diameter. Two of these specimens were fabricated. One specimen was used in the time-to-failure creep test with constant load of $100 \mathrm{MPa}$ at $800^{\circ} \mathrm{C}$. All of the creep tests were conducted in air.

(a)

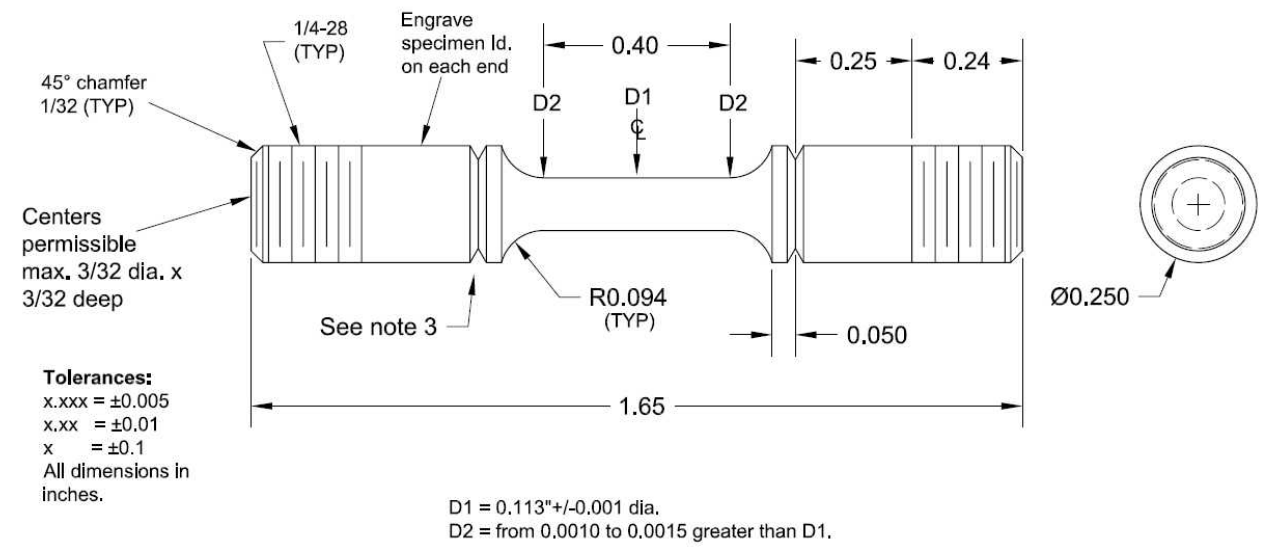

(b)

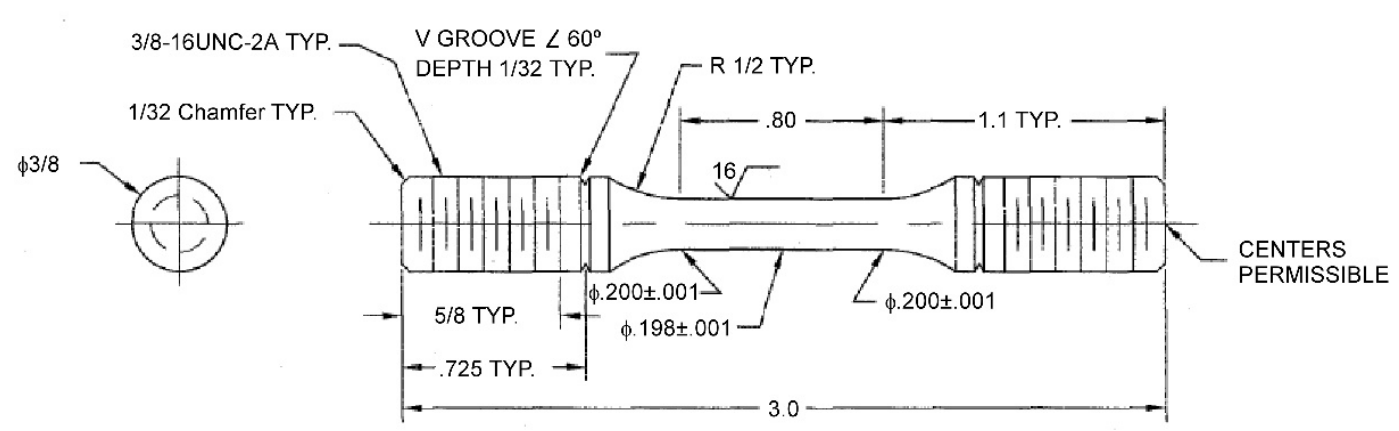

Figure 19. Dimensions of the specimens used in creep tests consisting of (a) MTS constant stress control of 200,250 and $300 \mathrm{MPa}$ at $800^{\circ} \mathrm{C}$ and (B) time to failure at $100 \mathrm{MPa}$ and $800^{\circ} \mathrm{C}$.

Figure 20 shows creep curves obtained for SM10 using the MTS test frame in constant stress control at 200,250 and $300 \mathrm{MPa}$ at $800^{\circ} \mathrm{C}$. The creep curve for the test at $200 \mathrm{MPa}$ and $800^{\circ} \mathrm{C}$ does 
not show the variation of strain with time during the first $\sim 60$ hours due to Labview not storing the acquired data after these buffers became overloaded. However, screen images were saved to show the trend in strain evolution. The results showed that the time to failure decreased significantly with increasing stress at $800^{\circ} \mathrm{C}$. The time to failure occurred in $\sim 10$ minutes at the highest stress of $300 \mathrm{MPa}$ and increase in time to $\sim 4.75$ hours at $250 \mathrm{MPa}$ and to $102 \mathrm{~h}$ at the lowest stress of $200 \mathrm{MPa}$. Although these are short times to cause specimen failure, it should be mentioned that these stress levels are very high relative to the yield strength of $14 \mathrm{YWT}-\mathrm{SM} 10$ at $800^{\circ} \mathrm{C}$, which is $395 \mathrm{MPa}$. These creep test conditions of 200,250 and $300 \mathrm{MPa}$ were more than $50 \%$ to $76 \%$ that of the yield strength. The creep curves also show strain increases rapidly during primary creep and transitioned to secondary creep in a short amount of time in the tests using 200, 250 and $300 \mathrm{MPa}$ at $800^{\circ} \mathrm{C}$. All of the tests indicated that secondary creep occurred over short durations that then ended with subsequent failure with essentially no evidence of tertiary creep. In addition, all 3 tests resulted in failure of the specimens at low $(<1 \%)$ levels of strain, which was unexpected.

The time-to-failure creep test that was conducted on SM10 at $800^{\circ} \mathrm{C}$ and $100 \mathrm{MPa}$ was started in April 2008 , but the test was unfortunately stopped a few years into the test with no specimen failure. The electronic data from the two Linear Variable Differential Transformers (LVDT) was recovered and processed. The data showed that the creep test was terminated at 20,327 hours, which correlates with 2.32 years. The creep curve of LVDT data for SM10 is shown in Figure 21. The creep strain increases rapidly at the start of the test reaching $0.167 \%$ strain in 1 hour. It then increased to $\sim 0.2 \%$ strain by 20 hours into the test. From there the creep strain increased slowly to $\sim 0.27 \%$ strain at 6,600 hours where it then slowly decreased with increasing time. The creep strain recorded at the termination time of 20,327 hours was $0.247 \%$ strain. The decrease in creep strain with time is not understood, but may be due to the expansion of the grips used in the creep test that also experienced 20,357 hours at $100 \mathrm{MPa}$ and near $800^{\circ} \mathrm{C}$.

The minimum creep rate (MCR) determined from the creep tests for SM10 are shown in Table 6. The MCR could not be determined for the time-to-failure creep test at $800^{\circ} \mathrm{C}$ and $1000 \mathrm{MPa}$ due to the slightly negative slope of the linear fit to the data. For the results of the constant stress control creep tests, the MCR increased with stress at $800^{\circ} \mathrm{C}$, which is expected for typical creep behavior. The lowest MCR recorded for SM10 was in the $200 \mathrm{MPa}$ test, which was $3.2 \times 10^{-10} \mathrm{~s}^{-1}$ and the highest MCR was $8.4 \times 10^{-6} \mathrm{~s}^{-1}$ in the $300 \mathrm{MPa}$ test. Based on these results, the MCR for the time-to-failure creep test at $800^{\circ} \mathrm{C}$ and $100 \mathrm{MPa}$ would most likely be lower than the MCR for the constant stress control test at $800^{\circ} \mathrm{C}$ and $200 \mathrm{MPa}$, which was $3.2 \times$ $10^{-10} \mathrm{~s}^{-1}$.

The common expression for relating minimum or secondary creep rate $\left(\dot{\varepsilon}_{m}\right)$ to stress $(\sigma)$ and absolute temperature $(\mathrm{T})$ is the temperature compensated power law relationship for creep:

$$
\dot{\varepsilon}_{m}=A \sigma^{n} \exp \left(\frac{-Q}{R T}\right)
$$

where $\mathrm{A}$ is a material constant, $n$ is the stress exponent, $\mathrm{Q}$ is the creep activation energy, $\mathrm{R}$ is the universal gas constant $(8.31 \mathrm{~J} / \mathrm{mol} \mathrm{K})$ and $\mathrm{T}$ is the absolute temperature. It is common to consider that values for the constants (A and $n$ ) and activation energy for creep (Q) will vary with the deformation mechanism during creep that depend on the stress and temperature conditions. The stress exponent $(n)$ provides information about creep mechanisms. Materials tested at high homologous temperatures typically have $n \cong 1$ indicating that creep diffusion is the dominant mechanism. For dispersion strengthened alloys, high values of $n$ indicate threshold stress behavior indicative of dislocation-particle interactions as the dominant creep mechanism for specific ranges of temperature and stress. The stress exponent is determined from the following relationship: 


$$
n=\left(\frac{\log \dot{\varepsilon}_{m}}{\log \sigma}\right)
$$

and is determined by plotting the values of the log minimum creep rate $\left(\dot{\varepsilon}_{m}\right)$, or strain rate from the SRJ test, against $\log$ stress $(\sigma)$ and measuring the slope from the exponential line fit.

Figure 22 shows the stress exponent $(n)$ calculated from the constant stress control creep tests for SM10 at stresses of 200,250 and $300 \mathrm{MPa}$ at $800^{\circ} \mathrm{C}$. The value obtained was $n=23.9$, which is consistent with the threshold stress behavior for 14YWT-SM10 with these creep test conditions.

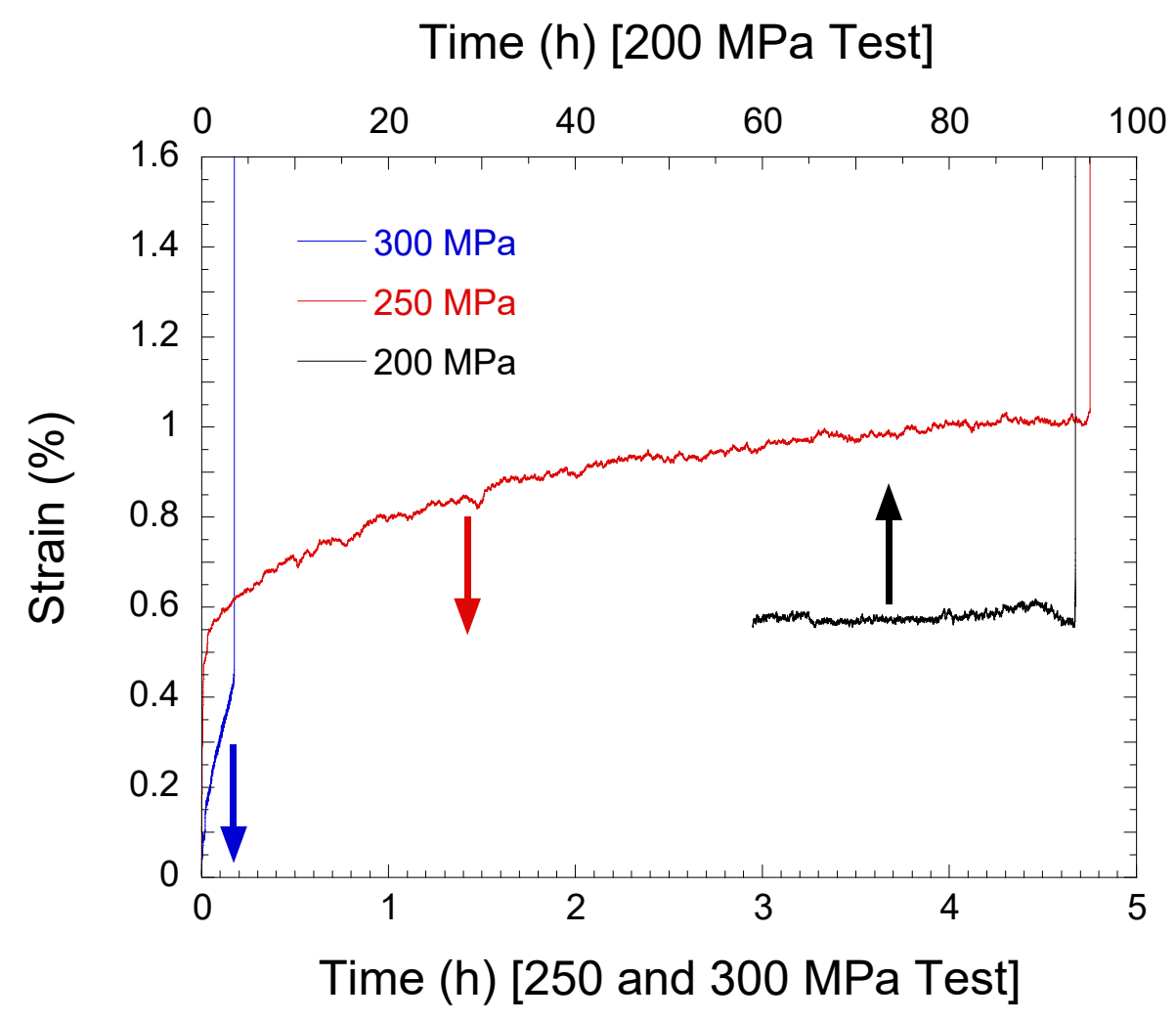

Figure 20. Creep curves of 14YWT-SM10 from constant stress controlled tests at $800^{\circ} \mathrm{C}$ and stresses of 200, 250 and $300 \mathrm{MPa}$. 


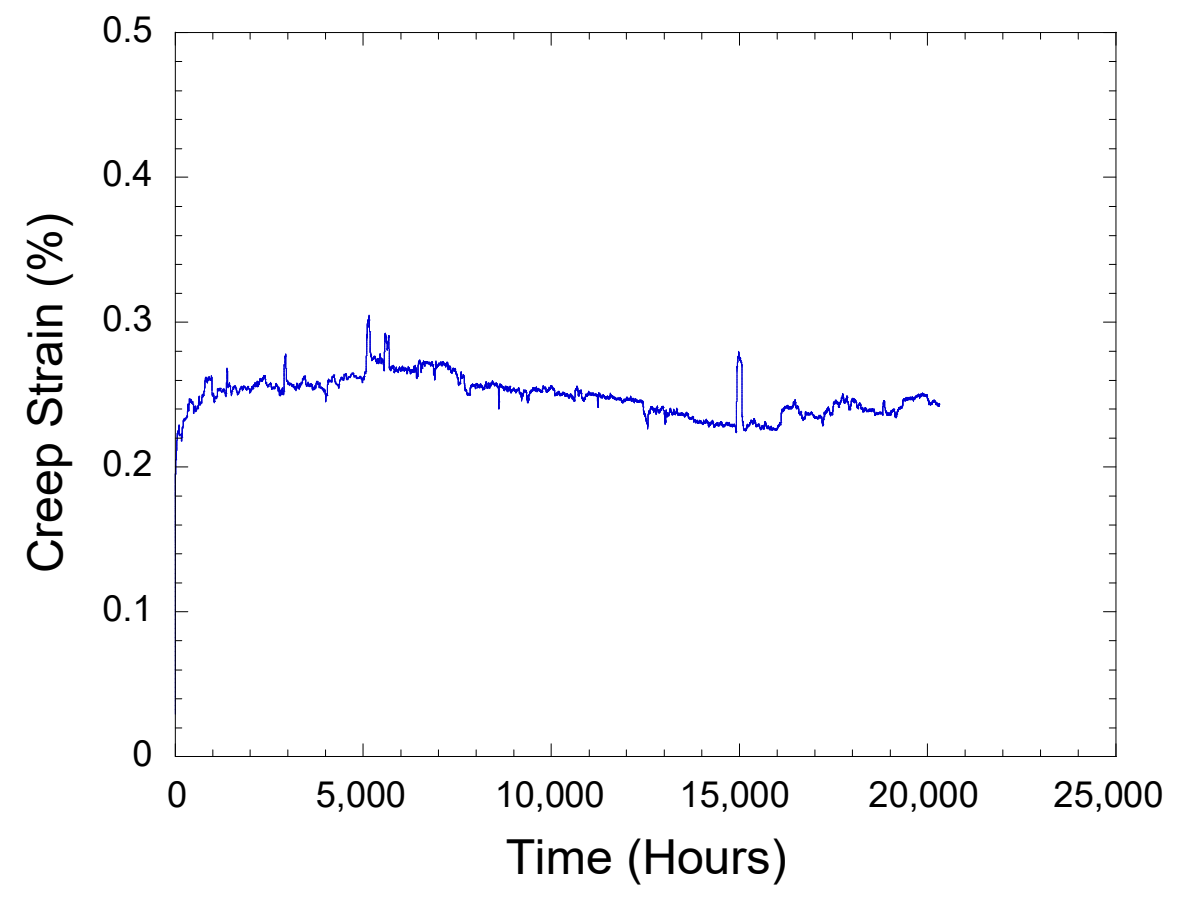

Figure 21. Creep curve of 14YWT-SM10 from time-to-failure test at $800^{\circ} \mathrm{C}$ and $100 \mathrm{MPa}$.

Table 6. The minimum creep rates (MCR) measured from the creep results for 14YWT-SM10.

\begin{tabular}{|c|c|c|}
\hline $\begin{array}{c}\text { Temperature } \\
\left({ }^{\circ} \mathrm{C}\right)\end{array}$ & $\begin{array}{c}\text { Stress } \\
(\mathrm{MPa})\end{array}$ & $\begin{array}{c}\mathrm{MCR} \\
\left(\mathrm{s}^{-1}\right)\end{array}$ \\
\hline $800^{\circ} \mathrm{C}$ & 100 & - \\
\hline $800^{\circ} \mathrm{C}$ & 200 & $3.2 \times 10^{-10}$ \\
\hline $800^{\circ} \mathrm{C}$ & 250 & $2.0 \times 10^{-7}$ \\
\hline $800^{\circ} \mathrm{C}$ & 300 & $6.4 \times 10^{-6}$ \\
\hline
\end{tabular}




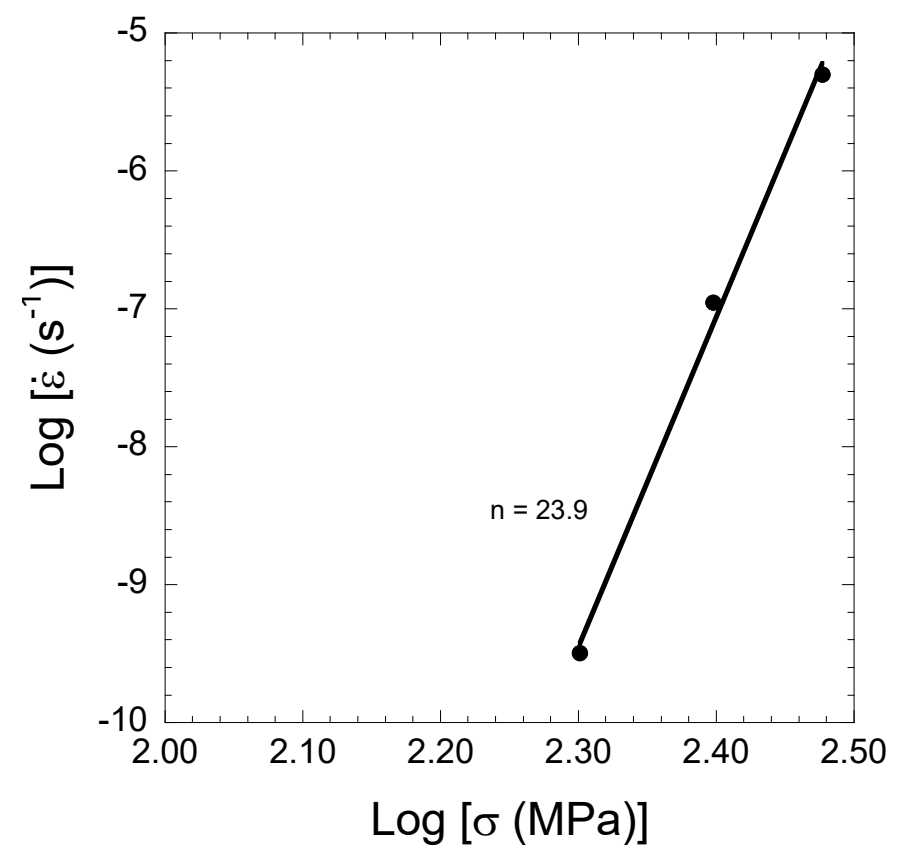

Figure 22. The calculated stress exponent $(n)$ from the constant stress control creep tests for SM10 at stresses of 200,250 and $300 \mathrm{MPa}$ at $800^{\circ} \mathrm{C}$.

\subsection{OFRAC}

The creep properties of OFRAC were determined using the strain-rate jump (SRJ) method. The SRJ test starts at the lowest strain rate based on the crosshead speed of the tensile machine while measuring the changes in stress. The stress increases with strain until it saturates and does not change with increasing strain. This value of stress is then correlated with the strain rate that was used. The strain rate is increased and the stress changes in response until it saturates and this procedure is then repeated until the final strain rate is reached that leads to specimen failure. The SRJ tests were conducted with SS-3 tensile specimens (Fig. 1) using an Instron 5900R screw driven tensile machine with convection heating. The SRJ tests for OFRAC were conducted at $550^{\circ} \mathrm{C}, 600^{\circ} \mathrm{C}, 700^{\circ} \mathrm{C}$ and $800^{\circ} \mathrm{C}$ in air.

Figure 23 shows the results of the strain-rate jump tests for OFRAC. The thermal creep behavior of OFRAC using the strain rate jump method at temperatures of 550,600, 700 and $800^{\circ} \mathrm{C}$. The SRJ tests started at $1.5 \times 10^{-7} \mathrm{~s}^{-1}$ and ended at $1.5 \times 10^{-3} \mathrm{~s}^{-1}$; each SRJ test ended when the stress no longer changed with time. The data showed similar creep stress exponent behavior for OFRAC over the temperature range of $550^{\circ} \mathrm{C}$ to $800^{\circ} \mathrm{C}$. The stress exponent $(n)$ was calculated from the results of the SRJ tests by plotting the data of the $\log$ strain rate $\left(\dot{\varepsilon}_{m}\right)$ against the log stress $(\sigma)$ and using an exponential line fit. The values of $n$ for all four SRJ tests on OFRAC are similar to that determined for 14YWT-SM10 (Fig. 22), which is consistent with the threshold stress behavior. 


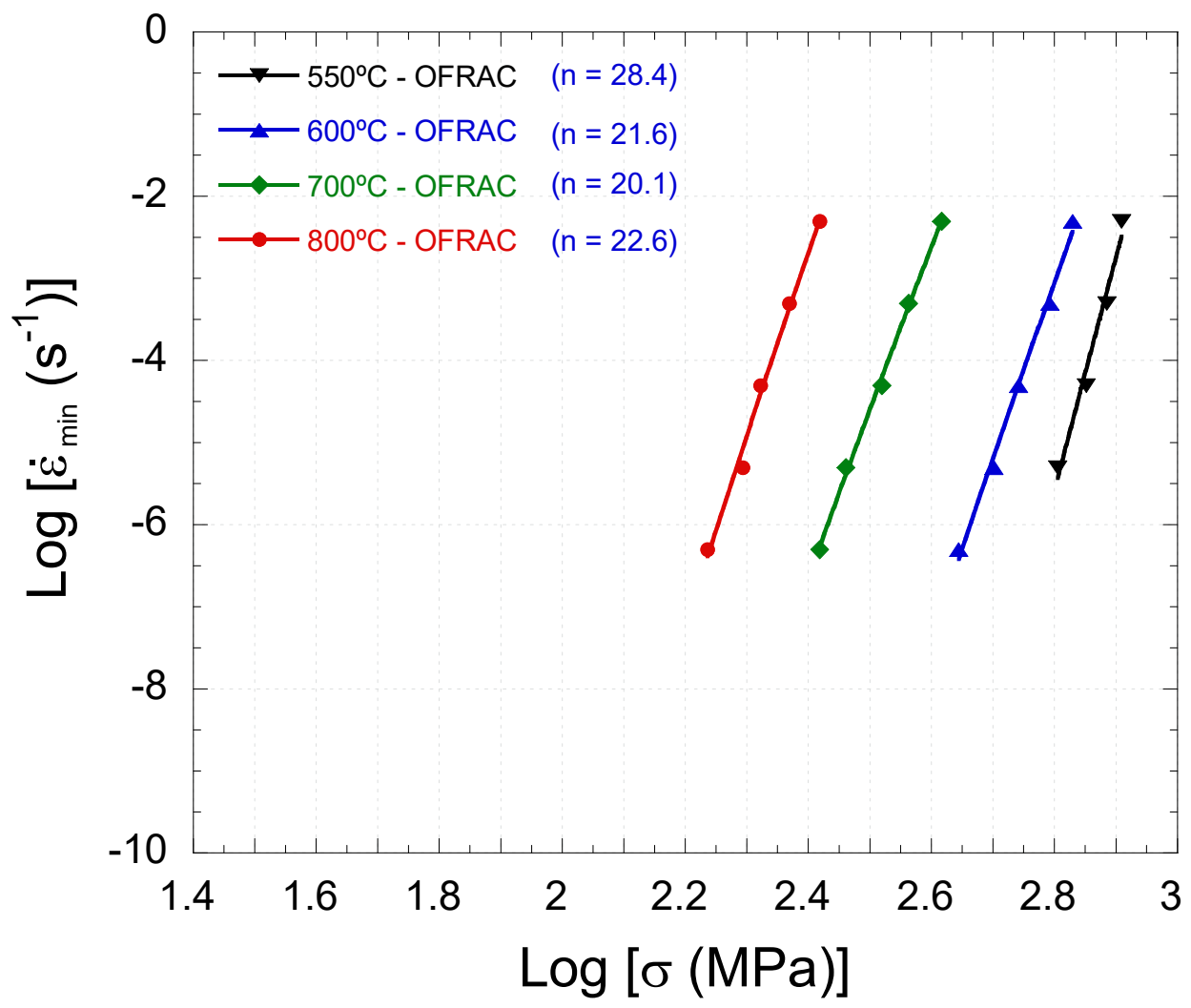

Figure 23. The thermal creep behavior of OFRAC using the strain-rate jump method at temperatures of $550,600,700$ and $800^{\circ} \mathrm{C}$.

\section{SUMMARY}

The tensile and creep properties of NFA 14YWT and OFRAC were compiled from previous testing at ORNL. The development of 14YWT started in 2000 and has resulted in the production of many heats over the past $\sim 20$ years. Tensile curves have been obtained from eleven 14YWT heats from room temperature to $800^{\circ} \mathrm{C}$. Only $14 \mathrm{YWT}-\mathrm{SM} 10$ has been tested to $1,000^{\circ} \mathrm{C}$. Overall, all $14 \mathrm{YWT}$ heats show high strength levels above $1200 \mathrm{MPa}$ at room temperature and several heats maintain strengths above $300 \mathrm{MPa}$ at $800^{\circ} \mathrm{C}$. The development history of 14YWT showed that the highest strength levels were achieved with SM7 and SM10, but that poor ductility and low fracture toughness properties at elevated temperatures led to development of improved mechanical alloying conditions for reducing $\mathrm{O}, \mathrm{N}$ and $\mathrm{C}$ contamination levels. This led to a new generation of 14YWT heats with more optimum strength, ductility, and fracture toughness (not shown in this report) properties. The tensile curves for the new generation of 14YWT heats show significant reductions in heat-to-heat variations in strength. The recently developed NFA OFRAC has tensile properties consistent with the new generation of 14YWT heats. The creep properties of 14YWTSM10 were evaluated at $800^{\circ} \mathrm{C}$ and was shown to have low minimum creep rates with stresses of 200 and $100 \mathrm{MPa}$. The single time-to-failure test of $14 \mathrm{YWT}-\mathrm{SM} 10$ at $800^{\circ} \mathrm{C}$ and $100 \mathrm{MPa}$ was terminated after 20,357 hours with no specimen failure and a low creep strain of $\sim 0.24 \%$. The creep properties of OFRAC determined from strain-rate jump tests suggest that the creep properties are similar to 14YWT-SM10. The stress exponent for $14 \mathrm{YWT}$ and $\mathrm{OFRAC}$ at $800^{\circ} \mathrm{C}$ are similar and are consistent with threshold stress behavior. 


\section{REFERENCES}

1. D.J. Larson, P.J. Maziasz, I.S. Kim, K. Miyahara, Scripta Materialia, "Three-dimensional atom probe observation of nanoscale titanium-oxygen clustering in an oxide-dispersion-strengthened Fe-12Cr-3W0.4T + Y2O3 ferritic alloy," Vol. 44(2), (2001), pp. 359-364.

2. D.T. Hoelzer, J. Bentley, M.A. Sokolov, M.K. Miller, G.R. Odette and M.J. Alinger, "Influence of particle dispersions on the high-temperature strength of ferritic alloys," Journal of Nuclear Materials, Vol. 367-370, (2007), pp. 166-172.

3. D.A. McClintock, D.T. Hoelzer, M.A. Sokolov, R.K. Nanstad, "Mechanical properties of neutron irradiated nanostructured ferritic alloy 14YWT," Journal of Nuclear Materials, Vol. 386-388, (2009), pp. 307-311.

4. J.H. Kim, T.S Byun, D.T. Hoelzer, S-W. Kim, B.H. Lee, “Temperature dependence of strengthening mechanisms in the nanostructured ferritic alloy 14YWT: Part I - Mechanical and microstructural observations," Materials Science \& Engineering A., Vol. 559, (2013), pp. 101-110.

5. J.H. Kim, T.S Byun, D.T. Hoelzer, C.H. Park, J.T. Yeom, J.K. Hong, "Temperature dependence of strengthening mechanisms in the nanostructured ferritic alloy 14YWT: Part II - Mechanistic models and predictions," Materials Science \& Engineering A., Vol. 559, (2013), pp. pp. 111-118.

6. T.S. Byun, J.H. Kim, J.H. Yoon, D.T. Hoelzer, "High temperature fracture characteristics of a nanostructured ferritic alloy (NFA)," Journal of Nuclear Materials, Vol. 407, (2010), pp. 78-82

7. D.T. Hoelzer, K.A. Unocic, M.A. Sokolov, T.S. Byun, "Influence of processing on the microstructure and mechanical properties of 14YWT," Journal of Nuclear Materials, Vol. 471, (2016), pp. 251-265.

8. D.T. Hoelzer, C.P. Massey, S.J. Zinkle, D.C. Crawford, K.A. Terrani, "Modern nanostructured ferritic alloys: A compelling and viable choice for sodium fast reactor fuel cladding applications," Journal of Nuclear Materials, Vol. 529, (2020), pp. 151928. 